\title{
Üstün Zekâlı ve Yetenekli Olan ve Üstün Zekâlı ve Yetenekli Olmayan Öğrencilerin Biyolojiye İlişkin Algılarının Karşılaştırılması: Metaforik Çalışma
}

\section{The Comparison of Gifted and Talented Students and Non Gifted Students' Perception of Biology: Metaphoric Study}

\author{
Murat ÖZARSLAN ${ }^{1}$
}

• Geliş Tarihi: 03.06.2018 • Kabul Tarihi: 20.06.2018 • Yayın Tarihi: 01.01.2019

\begin{abstract}
$\ddot{\mathbf{O z}}$
Bu çalışmanın amacı, üstün zekalı ve yetenekli öğrenciler ile üstün zekalı ve yetenekli olmayan öğrencilerin biyoloji kavramına ilişkin algılarının metaforlar yardımı ile karşılaştııılmasıdır. Çalışmada nitel araştırma desenlerinden olgubilim deseni kullanılmıştır. Çalışma grubu, kolay ulaşılabilir durum örneklemesi yöntemi ile belirlenmiştir. Çalışma grubu 2014-2015 akademik yılı bahar döneminde, Marmara bölgesinin 2 farklı ilindeki Bilim ve Sanat Merkezlerine (BİLSEM) devam eden 82 üstün zekâlı ve yetenekli öğrenci ile Marmara bölgesinde bir ortaokul ile bir Teknik ve Mesleki Anadolu Lisesinde öğrenim gören üstün zekâlı ve yetenekli olmayan 82 öğrenci ile gerçekleştirilmiştir. Verilerin analizinde içerik analizi kullanılmıştır. Her öğrencinin "Biyoloji.............. gibidir/benzer; çünkü............" cümlesini tamamlamasıyla veriler elde edilmiştir. Araştırma sonuçlarına göre, tüm katılımcıların biyoloji kavramına yönelik olarak çoğunlukla hayat/yaşam metaforlarını oluşturdukları gözlenmiş olup, biyolojiye yönelik olumlu bir algıya sahip oldukları tespit edilmiştir. Araştırmada; üstün zekalı ve yetenekli öğrencilerin üstün zekalı ve yetenekli olmayan öğrencilere göre biyolojiye yönelik daha fazla çeşitte metafor oluşturdukları belirlenmiştir. Ayrıca üstün zekâlı ve yetenekli öğrencilerin üstün zekâlı ve yetenekli olmayan öğrencilere göre biyolojinin merak uyandırıcı bir alan olduğunun daha fazla vurgulandığı tespit edilmiştir. Araştırmada üstün zekâlı ve yetenekli öğrenciler ile üstün zekâlı ve yetenekli olmayan öğrencilerin biyolojiye yönelik algıları arasında istatistiksel olarak anlamlı bir ilişki bulunamamıştır.
\end{abstract}

Anahtar Sözcükler: Üstün zekalı ve yetenekli öğrenciler, BİLSEM, biyoloji, metafor

\section{Önerilen Atıf Bilgisi:}

Özarslan, M.(2019). Üstün zekâlı ve yetenekli olan ve üstün zekâlı ve yetenekli olmayan öğrencilerin biyolojiye ilişkin algılarının karşılaştırılması: Metaforik çalışma. Pamukkale Üniversitesi Ĕgitim Fakültesi Dergisi, 45, 310-334.

\footnotetext{
${ }^{1}$ Dr. MEB Biyoloji Öğretmeni, ORCID: 0000-0003-2139-4347, muratozarslan14@ gmail.com,
} 
Üstün zekâlı ve yetenekli olan ve üstün zekâlı ve yetenekli olmayan öğrencilerin biyolojiye ilişkin algılarının karşılaştırılması: Metaforik çalışma

\begin{abstract}
The aim of this study is to compare gifted and talented students and non-gifted students' perception of Biology with the help of metaphors. Phenomenology Design from qualitative research designs is used in the study. The study group is decided through the method of convenience sampling. The study is fulfilled with the study group that consists of 82 gifted and talented students who have attended Science and Art Centre in two different cities of Marmara region and 82 non gifted students who have been studying in a secondary school and a Vocational and Technical Anatolian High school in Marmara region in the Spring term of 2014-2015 education year. The data is obtained through asking students to complete the sentence "Biology is like.........; because............." According to research results, it is observed that all participants usually create life and experience metaphors related to the concept of Biology and it is retained that the participants have a positive perception towards Biology. In the research, it is determined that gifted and talented students are able to create more various metaphors towards Biology than non-gifted students. Moreover, it is retained that gifted and talented students emphasize more than non-gifted ones that Biology is an intriguing field. In the research, there is not a statistically significant relationship found between the gifted and talented students and non-gifted ones' perception of Biology.
\end{abstract}

Keywords: Gifted and talented students, Science and Art Centre, Biology, Metaphor

\title{
Giriş
}

Toplumların geleceğe yönelik sahip olduğu firsatlardan biri de iyi yetişmiş insan gücüdür. Bir toplumu geleceğe taşıyacak yetişmiş insan gücünün en önemli grubu üstün zekalı ve yetenekli bireylerdir. Akranlarına göre bir veya daha fazla yetenek alanında üstün performans gösteren ve diğer alanlarda da ortalama düzeyde özelliklere sahip bireylere üstün zekalı ve yetenekli denilmektedir (Ataman, 2009). Ülkemizde ise Milli Eğitim Bakanlığı (MEB) tarafından zekâ, yaratıcılık, sanat, liderlik kapasitesi veya özel akademik alanlarda akranlarından daha yüksek düzeyde performans gösterdiği uzman kişilerce belirlenen öğrenciler üstün zekalı ve yeteneklidirler (MEB BİLSEM Yönergesi, 2007). Üstün zekalı ve yetenekli öğrenciler; hızlı öğrenmeleri, ileri düzeyde algılamaları, yüksek yaratıcılıkları, mükemmel hafızaları, geniş kelime dağarcığı, gelişmiş hayal güçleri, ilgi ve merak duyulan konularda yüksek dikkat, motivasyon göstermeleri vb. özelliklere sahip olabilmektedir (Akarsu, 2004; Levent, 2014; Sak, 2012). Bu öğrencilerin birçoğunun küçük yaştan itibaren en temel ilgi ve merak alanları fen bilimleridir(Van Tassel-Baska ve Stambaugh, 2009). Ayrıca bu öğrenciler kavram odaklı fen öğrenimine karşı da güçlü bir ilgiye sahiptirler (Van Tassel-Baska ve Stambaugh, 2009; Özarslan, 2015).

Üstün zekalı ve yetenekli olan ve üstün zekalı ve yetenekli olmayan öğrenciler kavramları algılarken genelde algılamak istediği kavramı başka bir kavrama benzetir ya da düşünülen iki kavramın ortak özelliklerine odaklanırlar. Bu şekil düşünmede metaforlar ön plana çıkmaktadır (Ocak ve Gündüz, 2006; Yapıc1, 2015). Gerçeği ortaya koymakta dilsel bir araç olan metaforlar (Töremen ve Döş, 2009), "benzetme ve mecaz" anlamında kullanılmaktadır (TDK, 2016). İnsanlar metaforlar yardımı ile algılarını, duygularını, düşüncelerini, olayları ve süreçlerini vb. nasıl gördüklerini farklı benzetmeler ve mecazlar kullanarak açıklamaya çalışmaktadır (Cerit, 2008; Girmen, 2007; Inbar, 1996). Lakoff ve Johnson (1980) tarafından ortaya konulan "Çağdaş Metafor Teorisi" ile metafor kavramı günümüzde farklı bir boyut kazanmıştır. Bu teoride, Lakoff (1993) ile Fredriksson ve Pelger (2016) metaforların, bireylerin zihinsel yapısındaki benzer kavramı kullanarak anlatmak istendiği kavrama yönelik duygu ve düşüncelerini ifade etmesine ve kompleks bilgilerin yanlış anlaşılmasının azaltılmasına yardımcı olmaktadır. Ayrıca Lakoff (1993) ile Jensen (2006) bilimsel çalışmalarda bireylerin karmaşı, soyut bir olay veya kavrama ilişkin anlama, alg1 ve deneyimlerinin ortaya konulması 
için metaforların veri toplama aracı olarak kullanılabileceğini ifade etmiştir. Bu noktada birçok alanda kullanılan metaforlar, eğitim alanında da anlaşılmayan, anlaşılması zor konu veya bazı kavramları, algıları, duygu ve düşünceleri daha anlaşılır şekilde ortaya koymak için veri toplamada kullanılmaktadır (Karaçam ve Aydın, 2014).

Biyoloji çok hızlı gelişen ve yaşama dair yeni bilgileri insanlara sunan bir bilim dalıdır. Biyoloji alanındaki bilgiler hem kendimize ve çevremizdeki canlılara ait bilgiler hem de çoğunlukla çıplak gözle görülemeyen soyut bilgilerdir. Dolayısıyla bu durum biyoloji dersinde yer alan konuların öğrenilmesini ve çeşitli metaforlar kullanmalarına neden olmaktadır. Yani biyoloji alanında öğrenciler zengin metaforlar kullanabilirler. Örneğin; öğrenciler DNA modelini; "merdiven" ve "bilgi bankası", "yaşam kitabı" canlıların beslenmesiyle ilgili ilişkileri; "besin zinciri-besin piramidi”, canlıların evcilleştirilememiş olduklarını belirtmek için; "vahşi doğa" gibi kavramsal metaforları kullanılabilirler (Ekici, 2016; Fredriksson ve Pelger, 2016).

Öğrenciler biyolojiyi veya biyoloji konularını ilgi çekici ve faydalı olarak görmektedir. Ancak öğrencilerin biyoloji dersinde genellikle zorlandıkları ve başarısız olabildikleri ifade edilmiştir. $\mathrm{Bu}$ bakış açışı doğrultusunda öğrencilerin biyoloji dersini ilerleyen süreçlerde sevmedikleri, biyoloji dersine karşı olumsuz alg1, duygu ve düşünceler geliştirdikleri rapor edilmiştir (Açışlı ve Kolomuç, 2012; Gül ve Yeşilyurt, 2010). Bu noktada öğrencilerin biyolojiyi öğrenmelerinde biyolojiyi nasıl algıladıkları büyük önem taşımaktadır (Ulukök, Bayram ve Selvi, 2015).

Biyoloji alanının daha iyi anlaşılması ve farklı fikirler üretilebilmesi açısından metaforlar önemlidir (Gürbüzoğlu Yalmancı ve Aydın, 2013). Metaforlar sayesinde öğrenciler biyoloji alanı kavramlarını zihinlerinde yapılandırabilecek ve açıklayabilecektir (Harrison ve Treagust, 2006). Alan yazında üstün zekalı ve yetenekli olmayan öğrencilerin biyoloji kavramlarına yönelik metaforlarının araştırıldığı çalışmalara daha fazla odaklanıldığ 1 görülmektedir (Yapıc1, 2015). Örneğin, biyoloji kavramı (Gürbüzoğlu Yalmancı ve Aydın, 2013; Yapıc1, 2015), biyolojik çeşitlilik (Selvi, 2007), sentetik biyoloji (Hellsten ve Nerlich, 2011), Türlerin Orijini: Doğal Seçilim (Al-Zahrani, 2008), genom kavramı (Andrzej, 2002; Heijkoop, 2013), doğa kavramı (Kahyaoğlu ve Kırıktaş, 2016), DNA'nın kompleks yapısı (Strauss, 2009), mikroskop (Ekici, 2016) gibi. Yapıcı (2015) ortaöğretim öğrencilerinin biyoloji kavramı ile ilgili yaptığı metafor çalışmasında öğrencilerin büyük çoğunluğunun biyolojiyi yaşamla ilişkilendirdiği ve en fazla "hayat" metaforu geliştirdiklerini tespit etmiştir. Ulukök vd., (2015) ile Gürbüzoğlu Yalmancı ve Aydın (2013) yaptığı metafor çalışmalarında ; öğretmen adaylarının biyolojiye yönelik genelde olumlu algıya sahip olduklarını ifade etmişlerdir. Bunlara ek olarak, öğretmen adaylarının "hayat, canlı, dünya ve genetik" metaforlarını çoğunlukla kullandıkları tespit edilmiştir. Ancak bazı öğretmen adaylarının biyoloji ile ilgili "nankör, zor, ölüm, hastalık, sıkıcı ve ezber" gibi olumsuz metaforları da belirlenmiştir (Ulukök vd., 2015).

Üstün zekâlı ve yetenekli olan ve üstün zekalı ve yetenekli olmayan öğrencilerin biyoloji kavramına yönelik algılarının karşılaştırmalı olarak metaforlar yardımı ile ortaya konulduğu çalışmalara alan yazında rastlanmamıştır. Bu çalışma ile biyoloji kavramına yönelik elde edilen metaforlar, üstün zekalı ve yetenekli öğrenciler ile üstün zekalı ve yetenekli olmayan öğrencilerin biyolojiye yönelik algısal farklılıklarının ortaya konulmasına katkı sağlayacaktır. $\mathrm{Bu}$ sayede biyoloji eğitiminin üstün zekâlı ve yetenekli olan ve üstün zekalı ve yetenekli 
Üstün zekâlı ve yetenekli olan ve üstün zekâlı ve yetenekli olmayan öğrencilerin biyolojiye ilişkin algılarının karşılaş̧ırılması: Metaforik çalışma

olmayan öğrencilerin ilgi, merak ve gereksinimlerini karşılayabilecek şekilde farklılaştırılması mümkün olacaktır. Bu nedenle bu çalışma sonuçlarının alanyazına önemli katkı sağlayacağı düşünülmektedir.

Çalışma, üstün zekalı ve yetenekli olan ve üstün zekalı ve yetenekli olmayan öğrencilerin biyoloji kavramına ilişkin algılarının metaforlar yardımı ile karşılaştırılması amacıyla gerçekleştirilmiştir. Bu amaç kapsamında şu problemlere cevap aranmıştır:

1. Üstün zekalı ve yetenekli olan ve üstün zekalı ve yetenekli olmayan öğrencilerin biyoloji kavramına ilişkin metaforları nelerdir?

2. Üstün zekalı ve yeteneklilik ile öğrencilerin biyoloji kavramına yönelik algılarına ilişkin kavramsal kategorilerin frekansları arasında istatistiksel olarak anlamlı bir ilişki var midır?

\section{Yöntem}

$\mathrm{Bu}$ çalışmada, nitel araştırma desenlerinden araştırmanın doğasına uygun olan "olgubilim (fenomenolojik) deseni” kullanılmıştır. Olgubilim; farkında olduğumuz, ancak bütünüyle ayrıntılı bir şekilde anlamlandıramadığımız olay, alg1, kavram vb. durumları araştırmayı sağlamaktadır (Yıldırım ve Şimşek, 2006). Olgubilim desenin de araştırmacı, katılımcının tecrübeleri ile ilgilenmekte, algılamaları ve olaylara yükledikleri anlamları araştırmaktadır (Akturan ve Esen, 2008).

\section{Çalışma Grubu}

Çalışma grubunu belirlenmesi, kolay ulaşılabilir durum örneklemesi yöntemi ile gerçekleştirilmiştir (Büyüköztürk vd., 2011). Çalışma amacı doğrultusunda araştırmanın çalışma grubunu 2014-2015 akademik yılı bahar döneminde, Marmara bölgesinin 2 farklı ilindeki Bilim ve Sanat Merkezlerine (BİLSEM) devam eden 82 üstün zekâlı ve yetenekli öğrenci ve yine aynı bölgede bir ortaokul ile bir Teknik ve Mesleki Anadolu Lisesinde öğrenim gören ve üstün zekalı ve yetenekli olmayan 82 öğrenci ile gerçekleştirilmiştir. Çalışmaya 11-15 yaş grubuna ait öğrenciler katılmıştır. Öğrencilerin sınıf düzeylerine göre dağılımı Tablo 1'de sunulmuştur.

Tablo 1. Öğrencilerin Sınıf Düzeylerine Göre Betimsel İstatikleri

\begin{tabular}{cccc}
\hline Sınıf Düzeyi & $\begin{array}{c}\text { Üstün Zekalı ve Yetenekli } \\
\text { Öğrenci }\end{array}$ & $\begin{array}{c}\text { Üstün Zekalı ve } \\
\text { Yetenekli Olmayan } \\
\text { Öğrenci }\end{array}$ & Toplam \\
\hline 5 & 18 & 16 & 35 \\
6 & 21 & 17 & 38 \\
7 & 18 & 17 & 35 \\
8 & 13 & 17 & 30 \\
9 & 12 & 15 & 27 \\
\hline Toplam & 82 & 82 & 164 \\
\hline
\end{tabular}

Öğrencilerin, üstün zekalı ve yetenekli olarak tanımlanması MEB uzmanları tarafından genel yetenek ve zeka testleri ile yapılmaktadır. Ülkemizde üstün zekalı ve yetenekli olarak tanılanan öğrenciler BİLSEM'lere örgün eğitimlerinin dışındaki zamanlarında devam etmektedirler. Öğrenciler BİLSEM programında kapsamında zenginleştirme etkinliklerine katılmaktadır. BİLSEM programında üstün zekâlı ve yetenekli öğrencilerin sırası ile uyum, 
destek, bireysel yetenekleri fark ettirme, özel yetenekleri geliştirme (ÖYG) ve proje üretimi eğitimlerine katılmaktadır (MEB BILSEM Yönergesi, 2007).

Çalışmaya katılan üstün zekalı ve yetenekli öğrenciler, BİLSEM'de biyoloji alanında bireysel yetenekleri fark ettirme, özel yetenekleri geliştirme (ÖYG) ve proje üretimi eğitimlerine katılan öğrencilerden oluşmaktadır.

\section{Uygulama ve Verilerin Toplanması}

Çalışma, 2014-2015 öğretim yılının bahar döneminde gerçekleştirilmiştir. Çalışmada üstün zekâlı ve yetenekli öğrencilerin ortaokul düzeyindeki BİLSEM programlarında biyoloji alanında etkinlik gerçekleştirdikleri için biyoloji alanı hakkında bilgi sahibi oldukları bilinmektedir. Üstün zekalı ve yetenekli olmayan öğrenciler ise ortaokul düzeyinde fen bilimleri dersi gördüklerinden biyoloji alanının tam olarak tanımayabilirler. Bu nedenle fen ve teknoloji ders öğretmeni tarafindan sadece üstün zekalı ve yetenekli olmayan öğrencilere fen ve teknoloji dersinde biyoloji alanının tanıtılmasına çalışılmıştır. Bu amaçla öğretmen biyoloji konuları ve çalışma alanı hakkında öğrencilere bilgi aktarılmış ve haftalık performans görevleri hazırlatılmıştır. Öğrenciler performans görevlerini sınıflarında diğer arkadaşları ile paylaşmış, hazırladıkları posterler ve panoları arkadaşlarına bir hafta boyunca sergilemişlerdir. Çalışma verilerinin toplanması belirtilen uygulamaların tamamlanması sonrasında gerçekleştirilmiştir.

Üstün zekalı ve yetenekli olan ve üstün zekalı ve yetenekli olmayan öğrencilerin biyoloji kavramına yönelik metaforik algılamalarını belirlemek için öncelikle ilgili alan yazın incelenmiştir (Ekici, 2016; Turhan Türkkan, Yeşilpınar Uyar, 2016; Aktamış ve Dönmez, 2016). Eğitim alanındaki birçok çalışmada metaforların veri toplama aracı olarak kullanıldığı belirlenmiştir (Guerrero ve Villamil, 2002; Jensen, 2006). Alan yazında yer alan metafor çalışmaları doğrultusunda öğrencilerin biyoloji kavramına yönelik metaforlarını belirlemek için öğrencilerden "Biyoloji... gibidir/ benzer; çünkü ...." cümlesini tamamlamaları istenmiştir. Bu cümlenin yazılı olduğu bir A4 kâğıdı öğrencilere verilmiştir. Öğrencilerin cümleleri tamamlamaları için süre sınırlamasına gidilmemiş ve tüm öğrencilerin tamamlaması beklenmiştir.

\section{Verilerin Analizi}

Çalışmada elde edilen veriler, içerik analizi yöntemiyle analiz edilmiştir (Yıldırım ve Şimşek, 2011). Öğrencilerin belirttiği metaforlar ve metaforların kullanılma nedenleri makale yazarı ve fen bilgisi eğitimi konusunda uzman iki araştırmacı tarafından ayrı ayrı analiz edilmiştir. Çalışmada elde edilen veriler analiz edilirken şu aşamalar takip edilmiştir (Ekici, 2016).

Kodlama ve Ayıklama Așaması: Öğrencilerden elde edilen veriler numaralandırılmış ve sırası ile bilgisayar ortamına aktarılmıştır. Öğrencilerin biyoloji kavramına yönelik metaforları üstün zekâlı ve yetenekli öğrenciler ve üstün zekalı ve yetenekli olmayanlar şeklinde ayrı ayrı değerlendirilmiştir. Metaforlar taşıdıkları anlam bakımından incelenmiş ve kodlamalar yapılmıştır.

Kategori Geliştirme: $\mathrm{Bu}$ aşamada, oluşturulan metafor grupları belirli bir tema ile ilişkilendirilmiştir. Böylece toplam 11 farklı kavramsal kategori oluşmuştur.

Geçerlik ve Güvenirliğin Sağlanması Aşaması: Araştırmanın güvenirliğini sağlamak için, araştırmada ulaşılan 11 kavramsal kategori altında verilen metaforların, söz konusu bir 
Üstün zekâlı ve yetenekli olan ve üstün zekâlı ve yetenekli olmayan öğrencilerin biyolojiye ilişkin algılarının karşılaştırılması: Metaforik çalışma

kavramsal kategoriyi temsil edip etmediğini belirlemek amaciyla uzman görüşüne başvurulmuştur. Araştırmacı ve uzman arasındaki görüş birliği dikkate alınarak Miles ve Huberman'ın (1994) formülü aracılığıyla güvenirlik 0.89 olarak hesaplanmıştır. Verilerin analizi sonrasında metaforların frekansı hesaplanmıştır. Öğrencilerin metaforları ve açıklamalarından bazı örnekler öğrenci numarası verilerek, “ ... ” (Ö64) veya (ÜÖ78) gibi aynen alıntı yapılarak belirtilmiştir (Yıldırım ve Şimşek, 2006). Üstün zekalı ve yetenekli öğrenciler ve üstün zekalı ve yetenekli olmayan öğrencilerin biyoloji kavramına yönelik algıları arasındaki ilişkiyi belirlemek için kavramsal kategori frekans değerleri SPSS 20 paket programına girilmiştir. Verilerin kategorik olması sebebiyle parametrik olmayan tekniklerden Ki Kare testi uygulanmıştır (Pallant, 2001).

\section{Bulgular}

Öğrencilerin biyoloji kavramına yönelik kullandıkları metaforların frekans dağılımı Tablo 2'de sunulmuştur.

Tablo 2'ye göre, biyolojiye ilişkin üstün zekalı ve yetenekli öğrencilerin 82 ve üstün zekalı ve yetenekli olmayan öğrencilerin ise 82 geçerli metafor oluşturdukları belirlenmiştir. Öğrencilerin oluşturduğu toplam metafor sayısının 164 olduğu görülmüştür. Üstün zekalı ve yetenekli öğrenciler biyoloji kavramına yönelik 65 (\%79.2) çeşit metafor oluşturuluşken ve üstün zekalı ve yetenekli olmayan öğrenciler ise biyoloji kavramına yönelik 44 (\%53.6) çeşit metafor oluşturduğu tespit edilmiştir. Sonuçta üstün zekalı ve yetenekli öğrencilerin üstün zekalı ve yetenekli olmayan öğrencilere göre daha fazla farklı metafor oluşturdukları söylenebilir.

Üstün zekalı ve yetenekli öğrencilerin çoğunlukla canlı (8) ve hayat/yaşam (5) metaforlarını, üstün zekalı ve yetenekli olmayan öğrencilerin ise çoğunlukla ve hayat/yaşam (13), bilim (6) ve insan (6) metaforlarını kullandıkları belirlenmiştir. Sonuçta üstün zekalı ve yetenekli öğrenciler ile üstün zekalı ve yetenekli olmayan öğrencilerin çoğunlukla hayat/yaşam metaforlarını ortak olarak ifade ettikleri görülmüştür. Ancak üstün zekalı ve yetenekli olmayan öğrencilerin farklı olarak çoğunlukla bilim ve insan metaforlarını oluşturdukları tespit edilmiştir.

Öğrencilerin biyoloji kavramına ilişkin oluşturdukları metaforların içerik analizi sonuçları ile oluşan kavramsal kategoriler ise; "Yaşamın kendisi olarak biyoloji", Anlaşılmaz/ karmaşık/zorlayıcı olarak biyoloji”, "Olumsuz bir duygu kaynağı olarak biyoloji”, "Sağlıla ilgili olarak biyoloji”, "Araştırma ve inceleme alanı olarak biyoloji”, "Bilim olarak biyoloji”, "Merak kaynağı olarak biyoloji”, "Eğlence ve mutluluk kaynağı olarak biyoloji”, "Araştırıcı ve bilgi sağlayıcı olarak biyoloji", "Çeşitlilik ve farklılık kaynağı olarak biyoloji” ve "Gereklilik bakımından biyoloji”" şeklinde olmak üzere 11 kategoride düzenlenmiştir. Bu kategorilere göre öğrencilerin kullandığı metaforların frekans dağılımları Tablo 3'de sunulmuştur. 
Tablo 2. Öğrencilerin "Biyolojiye" ilişkin sahip oldukları metaforların frekans dağılımları

\begin{tabular}{|c|c|c|c|c|c|c|c|c|c|c|c|}
\hline Metafor & $\begin{array}{l}\ddot{U} \\
f\end{array}$ & $\begin{array}{l}O \\
\text { f }\end{array}$ & $\begin{array}{l}\mathbf{T} \\
\mathbf{f}\end{array}$ & Metafor & $\begin{array}{l}\ddot{\mathbf{U}} \\
\mathbf{f}\end{array}$ & $\begin{array}{l}\mathbf{O} \\
\mathbf{f}\end{array}$ & $\begin{array}{l}\mathbf{T} \\
\mathbf{f}\end{array}$ & Metafor & $\begin{array}{l}\ddot{\mathbf{U}} \\
\mathbf{f}\end{array}$ & $\begin{array}{l}\mathbf{O} \\
\mathbf{f}\end{array}$ & $\begin{array}{l}\mathbf{T} \\
\mathbf{f}\end{array}$ \\
\hline Hayat/yaşam & 5 & 13 & 18 & Hava & - & 1 & 1 & Biz & 1 & - & 1 \\
\hline Canlı & 8 & 3 & 11 & Hayali güç & - & 1 & 1 & Deney & 1 & - & 1 \\
\hline Bilim & 1 & 6 & 7 & $\mathrm{Su}$ & - & 1 & 1 & Kimlik & 1 & - & 1 \\
\hline İnsan & - & 6 & 6 & Sikıc1 & - & 1 & 1 & Lunapark & 1 & - & 1 \\
\hline Hücre & 1 & 4 & 5 & Örümcek & - & 1 & 1 & Parti & 1 & - & 1 \\
\hline Tip & 1 & 4 & 5 & Araba motoru & - & 1 & 1 & Fizik & 1 & - & 1 \\
\hline Ders & 2 & 2 & 4 & Uzay & - & 1 & 1 & Hiçbir şey & 1 & - & 1 \\
\hline Fen bilimleri & 1 & 3 & 4 & Çin işkencesi & - & 1 & 1 & Bitki & 1 & - & 1 \\
\hline Bilim dalı & - & 3 & 3 & Korece & - & 1 & 1 & Dağınık oda & 1 & - & 1 \\
\hline Doğa & 1 & 2 & 3 & Fen dersi & - & 1 & 1 & Hayat dersi & 1 & - & 1 \\
\hline Arkadaş/dost & 2 & - & 2 & Daire & - & 1 & 1 & Güzel bir ders & 1 & - & 1 \\
\hline Yaşam tarzı & 2 & - & 2 & Jel & - & 1 & 1 & Güzel değil & 1 & - & 1 \\
\hline Büyüteç & 2 & - & 2 & Köpek & - & 1 & 1 & Botanik bahçesi & 1 & - & 1 \\
\hline Doktor & - & 2 & 2 & Canlıların arkadaş 1 & - & 1 & 1 & Sirlar & 1 & - & 1 \\
\hline Yaşam bilimi & 2 & - & 2 & Oyun & 1 & - & 1 & İ̆grenç & 1 & - & 1 \\
\hline Ağaç & 1 & 1 & 2 & İnceleme & 1 & - & 1 & Ayna & 1 & - & 1 \\
\hline Eğlenceli & 1 & 1 & 2 & Yeni alınmış kitap & 1 & - & 1 & X-Ray & 1 & - & 1 \\
\hline Zevkli & - & 2 & 2 & Çekirdek & 1 & - & 1 & Merak & 1 & - & 1 \\
\hline İnsan sağlığı & 1 & 1 & 2 & İlginç bilgiler & 1 & - & 1 & Akıl oyunu & 1 & - & 1 \\
\hline Hayatın & 2 & - & 2 & Meslek & 1 & - & 1 & Eğitim & 1 & - & 1 \\
\hline Öğretmen & - & 2 & 2 & Evren & 1 & - & 1 & Can yakar & 1 & - & 1 \\
\hline Kitap & 1 & 1 & 2 & Karanlık bir oda & 1 & - & 1 & Orman & 1 & - & 1 \\
\hline İp yumağ1 & 1 & - & 1 & Ben & 1 & - & 1 & Profesör & - & 1 & 1 \\
\hline Savaş & 1 & - & 1 & Bilgi & 1 & - & 1 & $\begin{array}{l}\text { Birbirine bağlı } \\
\text { döngü }\end{array}$ & - & 1 & 1 \\
\hline Gereksiz & 1 & - & 1 & Kadın & 1 & - & 1 & Sevdiğim bir & - & 1 & 1 \\
\hline Zooloji & 1 & - & 1 & İlaç & 1 & - & 1 & Sevgi duyulan & - & 1 & 1 \\
\hline Astronomi & 1 & - & 1 & Kimya & 1 & & 1 & İlim & - & 1 & 1 \\
\hline Farklı & 1 & - & 1 & Harika & 1 & - & 1 & Ruh & - & 1 & 1 \\
\hline $\begin{array}{l}\text { Çok dallı bir } \\
\text { ders }\end{array}$ & 1 & - & 1 & Geniş aile & 1 & - & 1 & MEB & - & 1 & 1 \\
\hline Makina & - & 1 & 1 & Tornavida & 1 & - & 1 & Bilim adamı & - & 1 & 1 \\
\hline Brokoli & - & 1 & 1 & Dünya & 1 & - & 1 & Sağlıklı yaşam & - & 1 & 1 \\
\hline Sarmal & - & 1 & 1 & Kalem & 1 & - & 1 & & & & \\
\hline DNA & - & 1 & 1 & Sanat & 1 & - & 1 & & & & \\
\hline
\end{tabular}

Ü: Üstün zekalı ve yetenekli öğrenci; O: Üstün zekalı ve yetenekli olmayan öğrenci; T: Toplam

Tablo 2'ye göre, biyolojiye ilişkin üstün zekalı ve yetenekli öğrencilerin 82 ve üstün zekalı ve yetenekli olmayan öğrencilerin ise 82 geçerli metafor oluşturdukları belirlenmiştir. Öğrencilerin oluşturduğu toplam metafor sayısının 164 olduğu görülmüştür. Üstün zekalı ve yetenekli öğrenciler biyoloji kavramına yönelik 65 (\%79.2) çeşit metafor oluşturuluşken ve üstün zekalı ve yetenekli olmayan öğrenciler ise biyoloji kavramına yönelik 44 (\%53.6) çeşit metafor oluşturduğu tespit edilmiştir. Sonuçta üstün zekalı ve yetenekli öğrencilerin üstün zekalı ve yetenekli olmayan öğrencilere göre daha fazla farklı metafor oluşturdukları söylenebilir. 
Üstün zekâlı ve yetenekli olan ve üstün zekâlı ve yetenekli olmayan öğrencilerin biyolojiye ilişkin algılarının karşılaştırılması: Metaforik çalışma

Üstün zekalı ve yetenekli öğrencilerin çoğunlukla canlı (8) ve hayat/yaşam (5) metaforlarını, üstün zekalı ve yetenekli olmayan öğrencilerin ise çoğunlukla ve hayat/yaşam (13), bilim (6) ve insan (6) metaforlarını kullandıkları belirlenmiştir. Sonuçta üstün zekalı ve yetenekli öğrenciler ile üstün zekalı ve yetenekli olmayan öğrencilerin çoğunlukla hayat/yaşam metaforlarını ortak olarak ifade ettikleri görülmüştür. Ancak üstün zekalı ve yetenekli olmayan ögrencilerin farklı olarak çoğunlukla bilim ve insan metaforlarını oluşturdukları tespit edilmiştir.

Öğrencilerin biyoloji kavramına ilişkin oluşturdukları metaforların içerik analizi sonuçları ile oluşan kavramsal kategoriler ise; "Yaşamın kendisi olarak biyoloji", Anlaşılmaz/ karmaşık/zorlayıcı olarak biyoloji”, "Olumsuz bir duygu kaynağı olarak biyoloji”, "Sağlıkla ilgili olarak biyoloji", "Araştırma ve inceleme alanı olarak biyoloji", "Bilim olarak biyoloji", "Merak kaynağı olarak biyoloji", "Eğlence ve mutluluk kaynağı olarak biyoloji", "Araştırıcı ve bilgi sağlayıcı olarak biyoloji", "Çeşitlilik ve farklılık kaynağı olarak biyoloji" ve "Gereklilik bakımından biyoloji”" şeklinde olmak üzere 11 kategoride düzenlenmiştir. Bu kategorilere göre öğrencilerin kullandığı metaforların frekans dağılımları Tablo 3'de sunulmuştur.

\section{Biyoloji Kavramına İlişkin Kavramsal Kategorilerin İncelenmesi}

\section{Yaşamın kendisi olarak biyoloji kavramsal kategorisi}

Araştırmaya katılan 12 (\%14.6) üstün zekalı ve yetenekli ve 12 (\%14.6) üstün zekalı ve yetenekli olmayan öğrencilerin biyoloji kavramına ilişkin oluşturdukları metaforların biyoloji kavramının yaşamla ile ilişkisine vurgu yaptıkları belirlenmiştir. Bu öğrencilerin oluşturdukları metaforların frekans dağılımları Tablo 3'te sunulmaktadır.

Tablo 3. "Yaşamın Kendisi Olarak Biyoloji" Kavramsal Kategorisine Vurgu Yapan Öğrencilerin Kullandıkları Metaforların Frekans Dağılımı

\begin{tabular}{lccc}
\hline \multirow{2}{*}{ Metafor } & $\begin{array}{c}\text { Üstün zekalı ve } \\
\text { yetenekli öğrenci }\end{array}$ & $\begin{array}{c}\text { Üstün zekalı ve yetenekli } \\
\text { olmayan ögrenci }\end{array}$ & Toplam \\
\cline { 2 - 4 } & $\mathbf{f}$ & $\mathbf{f}$ & $\mathbf{f}$ \\
\hline Hayat/yaşam & 5 & 12 & 17 \\
Hayatın bir parçası & 2 & - & 2 \\
Yaşam bilimi & 2 & - & 2 \\
Yaşam tarzı & 2 & - & 2 \\
Hayat Dersi & 1 & - & 1 \\
\hline Toplam & 12 & 12 & 24 \\
\hline
\end{tabular}

Tablo 3'e göre araştırmaya katılan 12 üstün zekalı ve yetenekli öğrencinin 5 farklı metafor ve 13 üstün zekalı ve yetenekli olmayan öğrencinin bir metafor oluşturduğu belirlenmiştir. Üstün zekalı ve yetenekli öğrenciler ve üstün zekalı ve yetenekli olmayan öğrencilerin biyoloji kavramına yönelik çoğunlukla ortak olarak "hayat/yaşam" $(5 ; 13)$ metaforlarını kullandıkları görülmektedir. Ayrıca üstün zekalı ve yetenekli öğrencilerin üstün zekalı ve yetenekli olmayan öğrencilere göre "hayatın bir parçası" (2), "yaşam bilimi" (2), "yaşam tarzı" (2) ve "hayat dersi" (1) metaforlarını oluşturdukları belirlenmiştir. Bu kategoride yer alan bazı metaforlarla ilgili ifadelere örnekler aşağıda verilmiştir.

Biyoloji hayat gibidir. Çünkü hayatımızın içindedir. (Üstün zekâll ve yetenekli 7. ögrenci $\left(\ddot{U} \ddot{O}_{7}\right)$

Biyoloji yaşam gibidir. Çünkü bizim yaşamımıza katkı sağlayan canlıları inceler. (ÜÖ78) 
Biyoloji hayat dersi gibidir. Çünkü hayatımız hakkında ondan çok şey öğreniriz. (Ü̈̈̈11) Biyoloji hayat gibidir. Çünkü yaşamı ögretir. (Üstün olmayan 10. ögrenci $\left(\ddot{O}_{10}\right)$

Biyoloji yaşam gibidir. Çünkü yaşamı anlatır, kolaylaştırır ve dersler verir. $\left(\ddot{O}_{12}\right)$

\section{Anlaşılmaz/Karmaşık/Zorlayıcı olarak biyoloji kavramsal kategorisi}

Araştırmaya katılan 5 (\%6) üstün zekalı ve yetenekli ve $8(\% 9.7)$ üstün zekalı ve yetenekli olmayan öğrencilerin biyoloji kavramına ilişkin oluşturduğu metaforlarında biyolojinin anlaşılmaz, karmaşık ve zor bir alan olduğuna vurgu yaptıkları belirlenmiştir. Bu öğrencilerin oluşturdukları metaforların frekans dağılımları Tablo 4'te sunulmaktadır.

Tablo 4. "Anlaşılmaz/Karmaşı/Zorlayıcı Olarak Biyoloji” Kavramsal Kategorisine Vurgu Yapan Öğrencilerin Kullandıkları Metaforların Frekans Dağılımı

\begin{tabular}{lccc}
\hline \multirow{2}{*}{ Metafor } & $\begin{array}{c}\text { Üstün zekah ve } \\
\text { yetenekli öğrenci }\end{array}$ & $\begin{array}{c}\text { Üstün zekalı ve yetenekli } \\
\text { olmayan öğrenci }\end{array}$ & Toplam \\
\cline { 2 - 5 } & f & f & f \\
\hline Makine & - & 1 & 1 \\
Korece & - & 1 & 1 \\
Sarmal & - & 1 & 1 \\
DNA & - & 1 & 1 \\
Birbirine bağlı döngü & - & 1 & 1 \\
Araba motoru & - & 1 & 1 \\
Uzay & - & 1 & 1 \\
Çin işkencesi & - & 1 & 1 \\
Evren & 1 & - & 1 \\
Dağınık oda & 1 & - & 1 \\
İp yumağ & 1 & - & 1 \\
Ben & 1 & - & 1 \\
Savaş & 1 & - & 13 \\
\hline Toplam & 5 & 8 & 1 \\
\hline
\end{tabular}

Tablo 4'e göre araştırmaya katılan 5 üstün zekalı ve yetenekli öğrencinin 5 farklı metafor ve 8 üstün zekalı ve yetenekli olmayan öğrencinin 8 farklı metafor oluşturdukları belirlenmiştir. Üstün zekalı ve yetenekli olmayan öğrencilerin "makine" (1), "Korece" (1), "sarmal” (1) ve "DNA" (1) gibi metaforları kullanarak biyolojinin zor ve karmaşık bir alan olduğunuzu belirtmişlerdir. Üstün zekalı ve yetenekli öğrenciler ise "evren"(1), "dağınık oda" (1), “ip yumağı" (1) ve "ben" (1) gibi metaforları oluşturmuşlardır. Üstün zekalı ve yetenekli öğrenciler ile üstün zekalı ve yetenekli olmayan öğrencilerin biyoloji kavramına yönelik ortak bir metafor kullanmamaları da ilginç görülmektedir. Bu kategoride yer alan bazı metaforlarla ilgili ifadelere örnekler aşağıda verilmiştir.

Biyoloji ip yumağı gibidir. Çünkü karışıtktır ve çözmek zordur. (Ü̈̈̈ $\left.{ }_{17}\right)$

Biyoloji savaş gibidir. Çünkü zordur. (Ü̈̈̈4)

Biyoloji dağınık oda gibidir. Çünkü çok karmaşık geliyor. (Ü̈̈̈

Biyoloji araba gibidir. Çünkü çok sayıda karışık parçası var. (Ö̈67)

Biyoloji Korece gibidir. Çünkü anlaşılması ve ezberlenmesi zordur. (Ö̈)

Biyoloji araba motoru gibidir. Çünkü çok karmaşıktır. $\left(\ddot{O}_{54}\right)$ 
Üstün zekâlı ve yetenekli olan ve üstün zekâlı ve yetenekli olmayan öğrencilerin biyolojiye ilişkin algılarının karşılaştırılması: Metaforik çalışma

\section{Olumsuz bir duygu kaynağı olarak biyoloji kavramsal kategorisi}

Araştırmaya katılan 5 (\%6) üstün zekalı ve yetenekli öğrenci ile $1(\% 1)$ üstün zekalı ve yetenekli olmayan öğrencilerin biyoloji kavramına ilişkin oluşturduğu metaforlarında biyolojiyi olumsuz duyguların kaynağı olarak gördükleri belirlenmiştir. Bu öğrencilerin oluşturdukları metaforların frekans dağılımları Tablo 5 'te sunulmaktadır.

Tablo 5. "Olumsuz Bir Duygu Kaynağı Olarak Biyoloji” Kavramsal Kategorisine Vurgu Yapan Öğrencilerin Kullandıkları Metaforların Frekans Dağılımları

\begin{tabular}{lccc}
\hline \multirow{2}{*}{ Metafor } & $\begin{array}{c}\text { Üstün zekalı ve yetenekli } \\
\text { öğrenci }\end{array}$ & $\begin{array}{c}\text { Üstün zekalı ve yetenekli } \\
\text { olmayan öğrenci }\end{array}$ & Toplam \\
\cline { 2 - 4 } & $\mathbf{f}$ & $\mathbf{f}$ & $\mathbf{f}$ \\
\hline Sikıcı & - & 1 & 1 \\
Hiçbir şey & 1 & - & 1 \\
Gereksiz & 1 & - & 1 \\
Can yakar & 1 & - & 1 \\
Ĭğrenç & 1 & - & 1 \\
Güzel bir şey değil & 1 & - & 1 \\
\hline Toplam & 5 & 1 & 6 \\
\hline
\end{tabular}

Tablo 5'e göre araştırmaya katılan 5 üstün zekalı ve yetenekli öğrencinin 5 farklı metafor ve üstün zekalı ve yetenekli olmayan öğrencinin ise 1 metafor oluşturduğu belirlenmiştir. Üstün zekalı ve yetenekli öğrenciler biyoloji kavramına yönelik olarak "hiçbir şey" (1), "gereksiz" (1), "can yakar" (1) ve "iğrenç" (1) gibi metaforları ifade etmişlerdir. Ayrıca bir üstün zekalı ve yetenekli olmayan öğrencinin "sıkıcı" (1) olumsuz duygu barındıran metaforu kullanmıştır. Sonuçta üstün zekalı ve yetenekli öğrencilerin biyoloji yönelik olumsuz duygularının üstün zekalı ve yetenekli olmayan öğrencilerden biraz daha fazla olduğu tespit edilmiştir. Bu kategoride yer alan bazı metaforlarla ilgili ifadelere örnekler aşağıda verilmiştir.

Biyoloji iğrenç gibidir. Çünkü derslerde incelediğimiz böcek ve bitkilerin içyapısı midemi bulandirlyor. $\left(\ddot{U} \ddot{O}_{29}\right)$

Biyoloji can yakar gibidir. Çünkü derslerde hayvanları keseriz. (Ü̈̈66)

Biyoloji güzel bir şey değil gibidir. Çünkü ezbere dayalıdır ve ben ezberden nefret ederim. (Ü̈̈80)

Biyoloji sıkıcı gibidir. Çünkü çalışırken sıkılıyorum. $\left(\ddot{O}_{28}\right)$

\section{Sağlıkla ilgili olarak biyoloji kavramsal kategorisi}

Araştırmaya katılan 2 (\%2.4) üstün zekalı ve yetenekli öğrenci ile 8 (\%9.7) üstün zekalı ve yetenekli olmayan öğrencilerin biyoloji kavramına ilişkin oluşturdukları metaforlarında sağlıkla ilgili kavramlara vurgu yaptıkları belirlenmiştir. $\mathrm{Bu}$ öğrencilerin oluşturdukları metaforların frekans dağılımları Tablo 6'da sunulmaktadır. 
Tablo 6. "Sağlıkla İlgili Olarak Biyoloji”" Kavramsal Kategorisine Vurgu Yapan Öğrencilerin Kullandıkları Metaforların Frekans ve Yüzde Dağılımları

\begin{tabular}{lccc}
\hline \multirow{2}{*}{ Metafor } & $\begin{array}{c}\text { Üstün zekalı ve } \\
\text { yetenekli öğrenci }\end{array}$ & $\begin{array}{c}\text { Üstün zekalı ve yetenekli } \\
\text { olmayan öğrenci }\end{array}$ & Toplam \\
\cline { 2 - 4 } & $\mathbf{f}$ & $\mathbf{f}$ & $\mathbf{f}$ \\
\hline Tip & 1 & 4 & 5 \\
Insan sağlı̆̆ & 1 & 1 & 2 \\
Doktor & - & 2 & 2 \\
Sağlıklı yaşam & - & 1 & 1 \\
\hline Toplam & 2 & 8 & 10 \\
\hline
\end{tabular}

Tablo 6'ya göre araştırmaya katılan 2 üstün zekalı ve yetenekli öğrencinin 2 farklı metafor ve 8 üstün zekalı ve yetenekli olmayan öğrencinin ise 4 farklı metafor oluşturdukları belirlenmiştir. Üstün zekalı ve yetenekli öğrenciler ve üstün zekalı ve yetenekli olmayan öğrencilerin ortak olarak biyoloji kavramına yönelik olarak "tıp" $(1 ; 4)$ ve "insan sağlığı" $(1 ; 1)$ metaforlarını belirtmişlerdir. Üstün zekalı ve yetenekli olmayan öğrenciler "doktor" (2), "sağlıklı yaşam" (1) metaforlarını sağlıkla ilgili olarak kullanmışlardır. Ayrıca üstün zekalı ve yetenekli olmayan öğrencilerin üstün zekalı ve yetenekli öğrencilere göre sağlıkla ilgili olarak daha fazla metafor ürettikleri tespit edilmiştir $(8 ; 2)$. Bu kategoride yer alan bazı metaforlarla ilgili ifadelere örnekler aşağıda verilmiştir.

Biyoloji tıp gibidir. Çünkü canlıları inceliyor. (Ü̈̈64)

Biyoloji tıp gibidir. Çünkü insanları doktorlar gibi inceliyor. $\left(\ddot{O}_{75}\right)$

Biyoloji doktor gibidir. Çünkü insan yapısını inceler. (Ö̈5)

Biyoloji sağlıklı yaşam gibidir. Çünkü sağllklı yaşamamızı sağlar. ( $\left.\ddot{O}_{33}\right)$

\section{Araștırma ve inceleme alanı olarak biyoloji kavramsal kategorisi}

Araştırmaya katılan 11 (\%13.4) üstün zekalı ve yetenekli ile 13 (\%15.8) üstün zekalı ve yetenekli olmayan öğrencilerin biyoloji kavramına ilişkin oluşturdukları metaforlarında araştırma ve inceleme alanı ile ilgili metaforlara vurgu yaptıkları belirlenmiştir. Bu öğrencilerin oluşturdukları metaforların frekans dağılımları Tablo 7'de sunulmaktadır.

Tablo 7. "Araştırma Ve İnceleme Alanı Olarak Biyoloji” Kavramsal Kategorisine Vurgu Yapan Öğrencilerin Kullandıkları Metaforların Frekans Dağılımları

\begin{tabular}{lccc}
\hline \multirow{2}{*}{ Metafor } & $\begin{array}{c}\text { Üstün zekalı ve yetenekli } \\
\text { öğrenci }\end{array}$ & $\begin{array}{c}\text { Üstün zekalı ve yetenekli } \\
\text { olmayan öğrenci }\end{array}$ & Toplam \\
\cline { 2 - 4 } & $\mathbf{f}$ & $\mathbf{f}$ & $\mathbf{f}$ \\
\hline Canlı & 8 & 3 & 11 \\
Hücre & 1 & 4 & 5 \\
İnsan & - & 6 & 6 \\
Dünya & 1 & - & 1 \\
Bitki & 1 & - & 1 \\
\hline Toplam & 11 & 13 & 24 \\
\hline
\end{tabular}

Tablo 7'e göre araştırmaya katılan 11 üstün zekalı ve yetenekli öğrencinin 4 farklı metafor ve 13 üstün zekalı ve yetenekli olmayan öğrencinin ise 3 farklı metafor oluşturdukları belirlenmiştir. Üstün zekalı ve yetenekli ve üstün zekalı ve yetenekli olmayan öğrenciler ortak olarak biyoloji kavramına yönelik "canlı" $(8 ; 3)$ ve "hücre" $(1 ; 4)$ metaforlarını oluşturmuşlardır. Üstün zekalı ve yetenekli olmayan öğrenciler ise çoğunlukla "insan” (6) 
Üstün zekâlı ve yetenekli olan ve üstün zekâlı ve yetenekli olmayan öğrencilerin biyolojiye ilişkin algılarının karşılaştırılması: Metaforik çalışma

metaforunu araştırma ve inceleme alanı ile ilgili olarak kullanmışlardır. Bu kategoride yer alan bazı metaforlarla ilgili ifadelere örnekler aşağıda verilmiştir.

Biyoloji canlı gibidir. Çünkü canlıları araştıran bilim dalıdır. (Ü̈̈̈6)

Biyoloji bitki gibidir. Çünkü genelde araştırmalar biyolojide bitkilere yöneliktir. (ÜÖ $\left.{ }_{59}\right)$

Biyoloji insan gibidir. Çünkü insandaki olayları inceler. $\left(\ddot{O}_{19}\right)$

Biyoloji hücre gibidir. Çünkü biyolojide onu inceleriz. $\left(\ddot{O}_{39}\right)$

\section{Bilim olarak biyoloji kavramsal kategorisi}

Araştırmaya katılan 8 (\%9.7) üstün zekalı ve yetenekli ile 17 (\%20.7) üstün zekalı ve yetenekli olmayan öğrencilerin biyoloji kavramına ilişkin oluşturdukları metaforlarında biyolojinin bilim ilgili durumuna vurgu yaptıkları belirlenmiştir. $\mathrm{Bu}$ öğrencilerin oluşturdukları metaforların frekans dağılımları Tablo 8'de sunulmaktadır.

Tablo 8. "Bilim Olarak Biyoloji”" Kavramsal Kategorisine Vurgu Yapan Öğrencilerin Kullandıkları Metaforların Frekans Dağılımları

\begin{tabular}{lccc}
\hline \multirow{2}{*}{ Metafor } & $\begin{array}{c}\text { Üstün zekalı vetenekli } \\
\text { ö̆grenci }\end{array}$ & $\begin{array}{c}\text { Üstün zekalı ve yetenekli } \\
\text { olmayan öğrenci }\end{array}$ & Toplam \\
\cline { 2 - 4 } & $\mathbf{f}$ & $\mathbf{f}$ & $\mathbf{f}$ \\
\hline Bilim & 1 & 6 & 7 \\
Fen bilimleri & 1 & 3 & 4 \\
Ağaç & 1 & 1 & 2 \\
Bilim dalı & - & 3 & 3 \\
Brokoli & - & 1 & 1 \\
İlim & - & 1 & 1 \\
Örümcek & - & 1 & 1 \\
Daire & - & 1 & 1 \\
Geniş aile & 1 & - & 1 \\
Kimya & 1 & - & 1 \\
Fizik & 1 & - & 1 \\
Zooloji & 1 & - & 1 \\
Astronomi & 1 & - & 25 \\
\hline Toplam & 8 & 17 & 1 \\
\hline
\end{tabular}

Tablo 8'e göre araştırmaya katılan 8 üstün zekalı ve yetenekli öğrencinin 8 farklı metafor ve 17 üstün zekalı ve yetenekli olmayan öğrencinin ise 8 farklı metafor oluşturdukları belirlenmiştir. Üstün zekalı ve yetenekli öğrenciler ve üstün zekalı ve yetenekli olmayan öğrencilerin ortak olarak biyoloji kavramına yönelik "bilim" $(1 ; 6)$, "fen bilimleri" $(1 ; 3)$ ve "ağaç" $(1 ; 1)$ metaforlarını kullanmışlardır. Üstün zekalı ve yetenekli öğrenciler bilim ile ilgili olarak "geniş aile" (1), "zooloji" (1) ve "astronomi" (1) gibi metaforları ifade etmişlerdir. Üstün zekalı ve yetenekli olmayan öğrenciler ise bilimle ilgili olarak "bilim dalı" (3) ve "brokoli" (1) gibi metaforları oluşturmuşlardır. Bu kategoride yer alan bazı metaforlarla ilgili ifadelere örnekler aşağıda verilmiştir.

Biyoloji fen bilimleri gibidir. Çünkü fen bilimlerinin dalıdır. (Ü̈̈̈5)

Biyoloji bilim gibidir. Çünkü araştırma yapar. $\left(\ddot{U}_{3}\right)$

Biyoloji astronomi gibidir. Çünkü astronomi uzayı incelerken biyolojide canlları inceler.

$\left(\ddot{U} \ddot{O}_{72}\right)$

Biyoloji bilim dalı gibidir. Çünkü insanları ve bitkileri inceleyen bilim dalıdır. $\left(\ddot{O}_{13}\right)$

Biyoloji ăgaç gibidir. Çünkü bilimin dalları olduğu gibi ă̆acında dalları vardır. ( $\left.\ddot{O}_{14}\right)$ 
Biyoloji brokoli gibidir. Çünkü bilimin dalları gibi çok düzgün şekilde dallanmıştır (Ö̈54)

\section{Merak kaynağı olarak biyoloji kavramsal kategorisi}

Araştırmaya katılan 5 (\%6) üstün zekalı ve yetenekli öğrenci biyoloji kavramına ilişkin oluşturduğu metaforlarında biyolojinin merak edilen özelliğine vurgu yaptıkları belirlenmiştir. $\mathrm{Bu}$ öğrencilerin oluşturdukları metaforların frekans dağılımları Tablo 9'da sunulmaktadır.

Tablo 9. "Merak Kaynağı Biyoloji”" Kavramsal Kategorisine Vurgu Yapan Öğrencilerin Kullandıkları Metaforların Frekans Dağılımları

\begin{tabular}{lccc}
\hline \multirow{2}{*}{ Metafor } & $\begin{array}{c}\text { Üstün zekalı ve yetenekli } \\
\text { öğrenci }\end{array}$ & $\begin{array}{c}\text { Üstün zekalı ve yetenekli } \\
\text { olmayan ögrenci }\end{array}$ & Toplam \\
\cline { 2 - 4 } & $\mathbf{f}$ & $\mathbf{f}$ & $\mathbf{f}$ \\
\hline Yeni alınmış kitap & 2 & - & 2 \\
Çekirdek & 1 & - & 1 \\
Karanlık bir oda & 1 & - & 1 \\
Merak & 1 & - & 1 \\
Sirlar & 1 & - & 1 \\
\hline Toplam & 6 & - & 6 \\
\hline
\end{tabular}

Tablo 9'a göre araştırmaya katılan 6 üstün zekalı ve yetenekli öğrencinin 5 farklı metafor oluşturduğu belirlenmiştir. Ancak üstün zekalı ve yetenekli olmayan öğrencilerin ise biyolojinin merak edilen özelliğine yönelik metafor oluşturmadıkları belirlenmiştir. Üstün zekalı ve yetenekli olan öğrenciler biyolojinin merak uyandıran özelliği ile ilgili olarak "yeni alınmış kitap" (2), "çekirdek" (1) ve "karanlık oda" (1) gibi metaforları ifade etmişlerdir. Sonuç olarak üstün zekalı ve yetenekli ögrencilerin biyolojinin merak uyandırıcı yönüne üstün zekalı ve yetenekli olmayan öğrencilere göre daha fazla vurgu yaptığı söylenilebilir. Bu kategoride yer alan bazı metaforlarla ilgili ifadelere örnekler aşağıda verilmiştir:

Biyoloji ilginç strlar gibidir. Çünkü biyoloji dersinde ilginç şeyler görüyoruz. (Ü̈̈̈7)

Biyoloji yeni alınmış kitap gibidir. Çünkü yeni bir kitap aldı̆̆ımda onu okumak için can atarım. Biyolojide bu şekildedir. (Ü̈̈̈)

Biyoloji çekirdek gibidir. Çünkü biyolojiye başlarsan birakamazsın. $\left(\ddot{U}_{23}\right)$

\section{Eğlence ve mutluluk kaynağı olarak biyoloji}

Araştırmaya katılan $7(\% 8.5)$ üstün zekalı ve yetenekli öğrenci ile $7(\% 8,5)$ üstün zekalı ve yetenekli olmayan öğrencilerin biyoloji kavramına ilişkin oluşturdukları metaforlarında biyolojinin eğlence ve mutluluk kaynağı olma yönüne vurgu yaptıkları belirlenmiştir. Bu öğrencilerin oluşturdukları metaforların frekans dağılımları Tablo 10'da sunulmaktadır.

Tablo 10'a göre araştırmaya katılan 7 üstün zekalı ve yetenekli öğrencinin 7 farklı metafor ve 7 üstün zekalı ve yetenekli olmayan öğrencinin ise 6 farklı metafor oluşturdukları belirlenmiştir. Üstün zekalı ve yetenekli ve üstün zekalı ve yetenekli olmayan öğrenciler ortak olarak biyolojinin eğlence ve mutluluk kaynağı ile ilgili olarak "eğlenceli" $(1 ; 1)$ metaforunu ifade etmişlerdir. Ayrıca üstün zekalı ve yetenekli öğrenciler "lunapark" (1), "parti" (1) ve "harika" (1), "akıl oyunu" (1) gibi metaforları da ortaya koymuşlardır. Üstün zekalı ve yetenekli olmayan öğrenciler ise "zevkli” (2), "köpek" (1) ve "sevdiğim bir kitap" (1) gibi biyoloji kavramına yönelik olumlu duygu ve düşünceler içeren metaforlar oluşturmuşlardır 
Üstün zekâlı ve yetenekli olan ve üstün zekâlı ve yetenekli olmayan öğrencilerin biyolojiye ilişkin algılarının karşılaş̧ırılması: Metaforik çalışma

Tablo 10. "Eğlence ve Mutluluk Kaynağı Olarak Biyoloji” Kavramsal Kategorisine Vurgu Yapan Öğrencilerin Kullandıkları Metaforların Frekans Dağılımları

\begin{tabular}{lccc}
\hline \multirow{2}{*}{ Metafor } & $\begin{array}{c}\text { Üstün zekalı ve yetenekli } \\
\text { öğrenci }\end{array}$ & $\begin{array}{c}\text { Üstün zekalı ve yetenekli } \\
\text { olmayan öğrenci }\end{array}$ & Toplam \\
\cline { 2 - 4 } & $\mathbf{f}$ & $\mathbf{f}$ & $\mathbf{f}$ \\
\hline Eğlenceli & 1 & 1 & 2 \\
Zevkli & - & 2 & 2 \\
Jel & - & 1 & 1 \\
Köpek & - & 1 & 1 \\
Sevdiğim bir kitap & - & 1 & 1 \\
Sevgi duyulan & - & 1 & 1 \\
Lunapark & 1 & - & 1 \\
Parti & 1 & - & 1 \\
Harika & 1 & - & 1 \\
Akı1 oyunu & 1 & - & 1 \\
Güzel bir ders & 1 & - & 1 \\
Oyun & 1 & - & 1 \\
\hline Toplam & 7 & 7 & 14 \\
\hline
\end{tabular}

$\mathrm{Bu}$ kategoride yer alan bazı metaforlarla ilgili ifadelere örnekler aşağıda verilmiştir:

Biyoloji eğlenceli gibidir. Çünkü ögrenilmesi kolaydır. (ÜÖ

Biyoloji oyun gibidir. Çünkü eğlencelidir. $\left(\ddot{U} \ddot{O}_{41}\right)$

Biyoloji parti gibidir. Çünkü eğlencelidir. (Ö̈66)

Biyoloji zevkli gibidir. Çünkü canlıların yapısını inceler. $\left(\ddot{O}_{70}\right)$

Biyoloji eğlenceli gibidir. Çünkü canlıların ögreniyoruz. $\left(\ddot{O}_{40}\right)$

Biyoloji oyun gibidir. Çünkü eğlenceli ve basittir. $\left(\ddot{O}_{62}\right)$

\section{Araștırıcı ve bilgi sağlayıcı olarak biyoloji kavramsal kategorisi}

Araştırmaya katılan $16(\% 19.5)$ üstün zekalı ve yetenekli öğrenci ile $7(\% 10.9)$ üstün zekalı ve yetenekli olmayan öğrencilerin biyoloji kavramına ilişkin oluşturdukları metaforlarında biyolojinin araştırıcı ve bilgi sağlayıcı yönüne vurgu yaptıkları belirlenmiştir. Bu öğrencilerin oluşturdukları metaforların frekans dağılımları Tablo 11'de sunulmaktadır.

Tablo 11'e göre, araştırmaya katılan 16 üstün zekalı ve yetenekli öğrencinin 14 farklı metafor ve 9 üstün zekalı ve yetenekli olmayan öğrencinin ise 7 farklı metafor oluşturdukları belirlenmiştir. Üstün zekâlı ve yetenekli ve üstün zekalı ve yetenekli olmayan öğrenciler biyoloji kavramının araştırıcı ve bilgi sağlayıcı yönü ile ilgili ortak olarak "ders" $(2 ; 2)$ ve "kitap" (1;1) metaforlarını ifade etmişlerdir. Ayrıca üstün zekâlı ve yetenekli öğrenciler "büyüteç" (2), "biz” (1), “deney” (1),"kimlik” (1) ve "eğitim” (1) gibi metaforlarını oluşturmuşlardır. Üstün zekâlı ve yetenekli olmayan öğrenciler ise "öğretmen" (2), "profesör" (1) ve "bilim adamı" (1) gibi biyoloji kavramının araştırma ve bilgi sağlayıcı özelliklerine yönelik metaforlar ortaya koymuşlardır. 
Tablo 11. “Araştırıcı ve Bilgi Sağlayıcı Olarak Biyoloji” Kavramsal Kategorisine Vurgu Yapan Öğrencilerin Kullandıkları Metaforların Frekans Dağılımları

\begin{tabular}{|c|c|c|c|}
\hline \multirow[t]{2}{*}{ Metafor } & $\begin{array}{l}\text { Üstün zekalı ve } \\
\text { yetenekli öğrenci }\end{array}$ & $\begin{array}{l}\text { Üstün zekalı ve yetenekli } \\
\text { olmayan öğrenci }\end{array}$ & Toplam \\
\hline & f & $\mathbf{f}$ & $\mathbf{f}$ \\
\hline Ders & 2 & 2 & 4 \\
\hline Kitap & 1 & 1 & 2 \\
\hline Öğretmen & - & 2 & 2 \\
\hline Profesör & - & 1 & 1 \\
\hline Bilim adamı & - & 1 & 1 \\
\hline Fen dersi & - & 1 & 1 \\
\hline MEB & - & 1 & 1 \\
\hline Büyüteç & 2 & - & 2 \\
\hline $\mathrm{Biz}$ & 1 & - & 1 \\
\hline Deney & 1 & - & 1 \\
\hline Kimlik & 1 & - & 1 \\
\hline Eğitim & 1 & - & 1 \\
\hline İnceleme & 1 & - & 1 \\
\hline Kalem & 1 & - & 1 \\
\hline Ayna & 1 & - & 1 \\
\hline X-Ray & 1 & - & 1 \\
\hline Tornavida & 1 & - & 1 \\
\hline $\begin{array}{l}\text { Çok dallı bir } \\
\text { ders }\end{array}$ & 1 & - & 1 \\
\hline Bilgi & 1 & - & 1 \\
\hline Toplam & 16 & 9 & 25 \\
\hline
\end{tabular}

$\mathrm{Bu}$ kategoride yer alan bazı metaforlarla ilgili ifadelere örnekler aşağıda verilmiştir:

Biyoloji biz gibidir. Çünkü kendimizi tanır ve ögreniriz. (Ü̈̈̈62)

Biyoloji bir ders gibidir. Çünkü bitkilerle ilgili her şeyi ögreniyoruz. (ÜÖ̈ $\left.{ }_{17}\right)$

Biyoloji bilgi gibidir. Çünkü canlılar hakkinda bize bilgi verir. (Ü̈̈̈25)

Biyoloji büyüteç gibidir. Çünkü canlıları inceliyor. (ÜÖ

Biyoloji inceleme gibidir. Çünkü hayvanların yaşamını ve yapısını inceler. $\left(\ddot{O}_{80}\right)$

Biyoloji ögretmen gibidir. Çünkü hücre hakkında bize bilgi veriyor. (Ö $\left.{ }_{77}\right)$

Biyoloji bilim adamı gibidir. Çünkü her gün yeni bilgiler ortaya koyar. $\left(\ddot{O}_{74}\right)$

Biyoloji mikroskop gibidir. Çünkü canlıları incelemek için kullanıyoruz. $\left(\ddot{O}_{45}\right)$

\section{1. Çeşitlilik ve farklılık kaynağı olarak biyoloji kavramsal kategorisi}

Araştırmaya katılan 6 (\%7.3) üstün zekalı ve yetenekli öğrenci ile $4(\% 4.8)$ üstün zekalı ve yetenekli olmayan öğrencilerin biyoloji kavramına ilişkin oluşturdukları metaforlarında biyolojinin çeşitlilik ve farklılık özelliklerine yönelik vurgu yaptıkları belirlenmiştir. $\mathrm{Bu}$ öğrencilerin oluşturdukları metaforların frekans dağılımları Tablo 12'de sunulmaktadır. 
Üstün zekâlı ve yetenekli olan ve üstün zekâlı ve yetenekli olmayan öğrencilerin biyolojiye ilişkin algılarının karşılaş̧ırılması: Metaforik çalışma

Tablo 12. "Çeşitlilik ve Farklılık Kaynağı Olarak Biyoloji”" Kavramsal Kategorisine Vurgu Yapan Öğrencilerin Kullandıkları Metaforların Frekans Dağılımları

\begin{tabular}{|c|c|c|c|}
\hline \multirow[t]{2}{*}{ Metafor } & $\begin{array}{l}\text { Üstün zekalı ve } \\
\text { yetenekli öğrenci }\end{array}$ & $\begin{array}{c}\text { Üstün zekalı ve yetenekli } \\
\text { olmayan öğrenci }\end{array}$ & Toplam \\
\hline & f & $\mathbf{f}$ & $\mathbf{f}$ \\
\hline Doğa & 1 & 2 & 3 \\
\hline Ruh & - & 1 & 1 \\
\hline Hayali güç & - & 1 & 1 \\
\hline Kadın & 1 & - & 1 \\
\hline Sanat & 1 & - & 1 \\
\hline Farklı & 1 & - & 1 \\
\hline Orman & 1 & - & 1 \\
\hline Botanik bahçesi & 1 & - & 1 \\
\hline Toplam & 6 & 4 & 10 \\
\hline
\end{tabular}

Tablo 12'e göre araştırmaya katılan 6 üstün zekalı ve yetenekli öğrencinin 6 farklı metafor ve 4 üstün zekalı ve yetenekli olmayan öğrencinin ise 3 farklı metafor oluşturdukları belirlenmiştir. Üstün zekalı ve yetenekli ve üstün zekalı ve yetenekli olmayan öğrenciler biyoloji kavramının biyolojinin çeşitlilik ve farklılık özellikleri ile ilgili ortak olarak "doğa" $(1 ; 2)$ metaforunu geliştirdikleri belirlenmiştir. Üstün zekalı ve yetenekli öğrenciler biyolojinin çeşitlilik ve farklılık özellikleri ile ilgili "kadın" (1), "sanat" (1) ve "orman"(1) gibi metaforları ortaya koymuşlardır. Üstün zekalı ve yetenekli olmayan öğrenciler ise "ruh" (1) ve "hayali güç" metaforlarını ifade etmişlerdir. Bu kategoride yer alan bazı metaforlarla ilgili ifadelere örnekler aşağıda verilmiştir.

Biyoloji farklı gibidir. Çünkü bitkilerin farklı özelliklerini konu edinir. (Ü̈̈̈5)

Biyoloji kadın gibidir. Çünkü farklıdır, kolay kırılır ve düzeltilmez. (Ü̈̈8I)

Biyoloji orman gibidir. Çünkü her türlü canlıyı içerir. (Ü̈̈

Biyoloji botanik bahçesi gibidir. Çünkü bitki ve hayvanlar gibi birçok farklı canliyı görebiliriz. (Ü̈̈̈)

Biyoloji hayali bir güç gibidir. Çünkü doğanın farklı özelliklerini içerir. (Ö $\left.{ }_{57}\right)$

Biyoloji doğa gibidir. Çünkü biyolojik çeşitliliği içerir. $\left(\ddot{O}_{52}\right)$

\section{Gereklilik bakımından biyoloji kavramsal kategorisi}

Araştırmaya katılan 4 (\%4.8) üstün zekalı ve yetenekli öğrenci ile 3 (\%3.6) üstün zekalı ve yetenekli olmayan öğrencilerin biyoloji kavramına ilişkin oluşturdukları metaforlarında biyolojinin gerekliliğine yönelik vurgu yaptıkları belirlenmiştir. Bu öğrencilerin oluşturdukları metaforların frekans dağılımları Tablo 13'de sunulmaktadır.

Tablo 13'e göre, araştırmaya katılan 4 üstün zekalı ve yetenekli öğrencinin 3 farklı metafor ve üstün zekalı ve yetenekli olmayan 3 öğrencinin ise 3 farklı metafor oluşturdukları belirlenmiştir. Üstün zekalı ve yetenekli öğrenciler biyoloji ile ilgili "arkadaş (dost)" (2), "meslek" (1) ve "hava" (1) metaforlarını kullanmışlardır. Diğer taraftan üstün zekalı ve yetenekli olmayan öğrenciler "su" (1), "ilaç" (1) ve "canlıların arkadaşı" (1) metaforlarını kullanmışlardır. Sonuçta hem üstün zekalı ve yetenekli hem de üstün zekalı ve yetenekli olmayan öğrencilerin biyoloji alanının hava, su, ilaç ve meslek gibi gerekli bir alan olduğuna vurgu yapmışlardır. 
Tablo 13. "Gereklilik Bakımından Biyoloji" Kavramsal Kategorisine Vurgu Yapan Öğrencilerin Kullandıkları Metaforların Frekans ve Yüzde Dağılımları

\begin{tabular}{lccc}
\hline \multicolumn{1}{c}{ Metafor } & $\begin{array}{c}\text { Üstün zekalı ve } \\
\text { yetenekli öğrenci }\end{array}$ & $\begin{array}{c}\text { Üstün zekalı ve yetenekli } \\
\text { olmayan öğrenci }\end{array}$ & Toplam \\
\cline { 2 - 4 } & $\mathrm{f}$ & $\mathrm{f}$ & $\mathrm{f}$ \\
\hline Arkadaş/Dost & 2 & - & 2 \\
Meslek & 1 & - & 1 \\
Hava & 1 & - & 1 \\
Su & - & 1 & 1 \\
İlaç & - & 1 & 1 \\
Canlıların arkadaşı & - & 1 & 1 \\
\hline Toplam & 4 & 3 & 7 \\
\hline
\end{tabular}

$\mathrm{Bu}$ kategoride yer alan bazı metaforlarla ilgili ifadelere örnekler aşağıda verilmiştir:

Biyoloji arkadaş gibidir. Çünkü onunla oyunlar oynar ve değerli vakit geçiririz. (ÜÖ̈)

Biyoloji mesleğimiz gibidir. Çünkü bizim için önemlidir. $\left(\ddot{U} \ddot{O}_{28}\right)$

Biyoloji su gibidir. Çünkü gereklidir. $\left(\ddot{O}_{41}\right)$

Biyoloji dost gibidir. Çünkü biyolojide herkese lazımdır. $\left(\ddot{O}_{51}\right)$

Öğrencilerin Üstün Zekâlı ve Yetenekli Olup Olmamasına Göre Biyoloji Kavramına Yönelik Algılarının Karşılaştırılması

Üstün zeka ve yeteneklilik ile öğrencilerin biyolojiye ilişkin metaforik algıları arasında ilişkiyi ortaya çıkarmak için Ki-Kare testi analizi uygulanmıştır. Bu duruma yönelik olarak analiz sonuçları Tablo 14'de sunulmuştur.

Tablo 14. Üstün Zeka ve Yeteneklilik ile Öğrencilerin Biyolojiye İlişkin Metaforik Algıları Arasında İlişkiye Ait Ki-Kare Testi Analizi

\begin{tabular}{|c|c|c|}
\hline \multirow[t]{2}{*}{ Kavramsal Kategoriler } & $\begin{array}{c}\text { Üstün zekâlı ve yetenekli } \\
\text { öğrenci }\end{array}$ & $\begin{array}{c}\text { Üstün zekalı ve } \\
\text { yetenekli olmayan } \\
\text { öğrenci }\end{array}$ \\
\hline & $\mathbf{f}$ & $\mathbf{f}$ \\
\hline Yaşamın kendisi olarak biyoloji & 12 & 12 \\
\hline Anlaşılmaz/karmaşık/zorlayıcı olarak biyoloji & 5 & 8 \\
\hline Olumsuz bir duygu kaynağı olarak biyoloji & 5 & 1 \\
\hline Sağlıkla ilgili olarak biyoloji & 2 & 8 \\
\hline Araştırma ve inceleme alanı olarak biyoloji & 11 & 13 \\
\hline Bilim olarak biyoloji & 8 & 17 \\
\hline Merak kaynağı olarak biyoloji & 6 & 0 \\
\hline Eğlence ve mutluluk kaynağı olarak biyoloji & 7 & 7 \\
\hline Araştırıcı ve bilgi sağlayıcı olarak biyoloji & 16 & 9 \\
\hline Çeşitlilik ve farklılık kaynağı olarak biyoloji & 6 & 4 \\
\hline Gereklilik bakımından biyoloji & 4 & 3 \\
\hline \multirow[t]{2}{*}{ Toplam } & 82 & 82 \\
\hline & $\mathrm{p}=.500$ & \\
\hline
\end{tabular}


Üstün zekâlı ve yetenekli olan ve üstün zekâlı ve yetenekli olmayan öğrencilerin biyolojiye ilişkin algılarının karşılaştırılması: Metaforik çalışma

Tablo 14'e göre üstün zekâlı ve yetenekli öğrenciler ile üstün zekalı ve yetenekli olmayan öğrencilerin "Yaşamın kendisi olarak biyoloji" $(12 ; 12)$ ve "Eğlence ve mutluluk kaynağı olarak biyoloji" (7;7) kategorilerine ortak olarak vurgu yaptıkları görülmektedir. Üstün zekalı ve yetenekli öğrencilerin "Olumsuz bir duygu kaynağı olarak biyoloji" $(5 ; 1)$, "Merak kaynağı olarak biyoloji” (6;0) ve "Araştırıcı ve bilgi sağlayıcı olarak biyoloji” (16;9) kategorilerindeki metaforlara üstün zekalı ve yetenekli olmayan öğrencilere göre daha fazla vurgu yaptıkları belirlenmiştir. Üstün zekalı ve yetenekli olmayan öğrenciler "Anlaşılmaz/karmaşık/zorlayıc1 olarak biyoloji” (5;8), "Sağlıkla ilgili olarak biyoloji" $(2 ; 8)$ ve "bilim olarak biyoloji” $(8 ; 17)$ kategorilerine üstün zekalı ve yetenekli öğrencilere göre daha fazla vurgu yapmışlardır.

Üstün zekalı ve yetenekli öğrenciler ile üstün zekalı ve yetenekli olmayan öğrencilerin biyolojiye ilişkin algılarına yönelik kavramsal kategorilerin frekansları Ki-Kare testi ile analiz edildiğinde, öğrencilerin üstün zekalı ve yetenekli olup olmamasına göre, öğrencilerin biyoloji kavramına ilişkin algıları arasında $\alpha=0.05$ düzeyinde istatistiksel olarak anlamlı ilişkinin olmadığı belirlenmiş̧tir. Bu bulgular doğrultusunda üstün zekalı ve yetenekli olmanın öğrencilerin biyolojiye ilişkin algıları üzerine etkisinin olmadığı düşünülebilir.

\section{Tartışma ve Sonuç}

Üstün zekâlı ve yetenekli olan ve üstün zekalı ve yetenekli olmayan öğrencilerin biyoloji kavramına ilişkin algılarının metaforlar yardımı ile karşılaştırılması amacıyla bu çalışma gerçekleştirilmiştir.

Araştırmada; hem üstün zekalı ve yetenekli öğrencilerin ve hem de üstün zekalı ve yetenekli olmayan öğrencilerin biyoloji kavramına yönelik olarak çoğunlukla hayat/yaşam metaforlarını oluşturduğu belirlenmiştir. Bu sonuç, alan yazında yer alan, öğrencilerin biyolojiyi yaşamla ilişkilendirdiği ve en fazla kullanılan metaforların hayat/yaşamla ilgili olduğu bulguları ile örtüşmektedir (Gürbüzoğlu Yalmancı ve Aydın, 2013; Yapıc1, 2015). Biyoloji, bireylerin kendi özelliklerinin farkına varması, yaşamla ilgili soruları ve olayları çözümlemesi ve anlaması, yaşamını kolaylaştırması ve sağlığının devamı noktasında dikkat çekici bir bilim dalıdır. Bu nedenle hem üstün zekalı ve yetenekli öğrencilerin hem de üstün zekalı ve yetenekli olmayan öğrencilerin biyolojiyi yaşamla ilişkilendirdiği düşünülmektedir. $\mathrm{Bu}$ sonucu destekleyen diğer bulgular ise öğrencilerin biyolojinin araştırma ve inceleme alanı kategorisinde dikkat çekici bir şekilde insan, canlı, bitki, dünya gibi metaforları oluşturdukları söylenilebilir. Sonuçta biyoloji eğitiminde ve üstün zekalı ve yetenekli öğrencilere yönelik etkinliklerin farklılaştırılmasında; yaşama dair konu ve örneklere yer verilmesi, insan vücudu ve özelliklerine vurgu yapılması, günlük yaşamı kolaylaştıracak ve sağlıklı yaşama katkı sağlayacak etkinliklere önem verilmesi öğrencilerin gereksinimlerini ve beklentilerinin karşılanması açısından faydalı olabilir.

Üstün zekalı ve yetenekli öğrencilerin üstün zekalı ve yetenekli olmayan öğrencilere göre biyolojiye yönelik daha fazla çeşitte (\%79.26; \%53.6) metafor oluşturdukları belirlenmiştir. Bu sonucun nedeni olarak, üstün zekalı ve yetenekli öğrencilerin özellikleri gösterilebilir. Çünkü üstün zekâlı ve yetenekli öğrencilerin; ilgilendikleri konularda yaratıcılık, öğrendiklerini yeni durumlara transfer etme, sıra dışı düşünme, düşünceler arası bağlantı kurma, kavramlar arasındaki ilişkileri fark etme, kelime dağarcığı, hayal gücü, özgün ve orijinal düşünebilme becerilerinin üstün zekalı ve yetenekli olmayan öğrencilere göre ileri derecede 
olduğu ifade edilmektedir (Ataman, 2009; Çağlar, 2004; Davis ve Rimm, 2004; Sak, 2012; Stuart ve Beste, 2011).

Üstün zekalı ve yetenekli öğrencileriler ile üstün zekalı ve yetenekli olmayan öğrencilerin biyolojiye kavramına yönelik algıları arasında istatiksel olarak anlamlı bir ilişki görülmemiştir. Ancak bazı öğrencilerin biyoloji kavramına yönelik algılarının kategorileri arasında bazı farklılıklar olduğu söylenilebilir. Örneğin, merak kaynağı olarak biyoloji kategorisinde üstün zekâlı ve yetenekli öğrencilerin biyolojinin merak uyandırıcı özelliğine yönelik daha fazla vurgu yaptıkları görülmektedir. Yani üstün zekalı ve yetenekli öğrencilerin biyolojiye yönelik meraklarının üstün olmayan öğrencilere göre daha fazla olduğu düşünülebilir. Çünkü bu öğrencilerin küçük yaşlardan itibaren fen bilimlerine ilgi duydukları ve bu alana yönelik meraklarının oldukça yüksek düzeyde olduğu belirtilmektedir (Van TasselBaska ve Stambaugh, 2009; Özarslan, 2015; Stuart ve Beste, 2011). Diğer taraftan çalışma sonuçları üstün zekalı ve yetenekli olmayan öğrencilerin biyolojiye yönelik meraklarının oldukça az düzeyde olduğunu düşündürmektedir. $\mathrm{Bu}$ nedenle fen bilimleri derslerinde öğrencilerin biyoloji ilgili konulara ilgi ve meraklarını olumlu yönde geliştirecek uygulamalara yer verilebilir.

Biyolojiye yönelik oluşturulan 'olumsuz bir duygu kaynağı olarak biyoloji' kategorisinde ise üstün zekalı ve yetenekli öğrencilerin üstün zekalı ve yetenekli olmayan ögrencilere göre daha fazla olumsuz duygu ve düşünce ifade eden metaforlara vurgu yaptıkları belirlenmiştir. Bu durumun nedeni olarak, üstün zekalı ve yetenekli öğrencilere verilen biyoloji eğitimlerinin bu öğrencilerin gereksinimleri ve merakları doğrultusunda gerek örgün eğitimlerinde gerekse BİLSEM'lerde yeterince farklılaştırılamamasından kaynaklanabilir. Çünkü birçok araştırmacı ve eğitimci normal okul programlarının üstün zekâlı ve yetenekli öğrencilerin eğitimsel ihtiyaçlarını karşılamadığını, programların çok yönlü ve yaratıcı özellikler taşıması gerektiğini ifade etmektedir (Baykoç, 2014; Kontaş, 2010; Palanc1, 2004). Ancak üstün zekalı ve yetenekli öğrenciler biyolojiye yönelik yüksek meraklarına rağmen, öğrencilerin eğitim-öğretim programlarına olumsuz duygu ve düşünce gelişimi, ilgisiz kalma, sıkılma, motivasyon düşüklüğü gibi sorunlar ortaya çıkmaktadır (Kontaş, 2009; Kök, 2012). Sonuçta, üstün zekâlı ve yetenekli öğrencilerin gerek BİLSEM'de gerekse örgün eğitimlerin de verilen biyoloji eğitimlerinin öğrencilerin gereksinimleri karşılayacak, ilgi ve meraklarının tatminini sağlayacak şekilde farklılaştırılması gerekmektedir. Böylece öğrencilerin daha iyi öğrenmeleri, olumlu duygu ve düşünce geliştirmeleri sağlanabilir (Tomlinson, 2015; Tortop, 2015).

Araştırmada üstün zekalı ve yetenekli olmayan öğrencilerin üstün zekalı ve yetenekli öğrencilere göre biyolojinin sağlıkla ilgili yönüne daha fazla vurgu yaptıkları belirlenmiştir. Bu sonuç, üstün zekalı ve yetenekli olmayan öğrencilerin biyoloji eğitimlerinde günlük yaşamla ilişkilendirme noktasında sağlıkla ilgili konuların önemli olduğunu düşünülebilir. Bu nedenle biyoloji derslerinde üstün zekalı ve yetenekli olmayan öğrencilerin ilgilerini çekmek ve öğrenilenleri öğrencilerin günlük yaşantıları ile ilişkilendirebilmeleri için eğitimlerde insan sağlığını ilgilendiren konulara fen ve biyoloji öğretmenleri tarafindan daha fazla vurgu yapılmalıdır (Cerrah, Özsevgeç ve Ayas, 2005). Ayrıca üstün zekalı ve yetenekli öğrencilerin biyoloji konularının farklılaştırılmasında da güncel sağlık sorunları vurgulanabilir. Böylece hem biyoloji konularının gündelik yaşam ile ilişkisi sağlanabilir hem de ileride birçoğu bilim insanı 
Üstün zekâlı ve yetenekli olan ve üstün zekâlı ve yetenekli olmayan öğrencilerin biyolojiye ilişkin algılarının karşılaştırılması: Metaforik çalışma

olabilecek bu öğrencilerin güncel sağlık sorunları hakkında ilgi ve merakları geliştirilebilir ve farkındalık oluşturulabilir. Böylece gelecekte üstün zekalı ve yetenekli bireylerin tüm insanlığ1 ilgilendiren güncel sağlık sorunlarının çözümüne yönelmesi sağlayabilir.

Üstün zekalı ve yetenekli olmayan öğrencilerin üstün zekalı ve yetenekli öğrencilere göre biyolojinin anlaşılmaz, karmaşık ve zorlayıcı yönüne daha fazla vurgu yaptıkları belirlenmiştir. Üstün zekalı ve yetenekli öğrencilerin biyoloji alanını daha az karmaşık ve zorlayıcı olarak görmesi bu öğrencilerin özelliklerinden kaynaklanabilir. Çünkü bu öğrenciler zekâ gerektiren uğraşların zorluklarından hoşlanmakta, karmaşık oyun veya işlemlerden zevk almakta ve yüksek zihinsel performans gerektiren uğraşlarda başarı göstermektedir (Stuart ve Beste, 2011). Sonuçta üstün zekalı ve yetenekli öğrencilerin farklılaştırılmış eğitimlerinde biyoloji alanının oldukça önemli bir konuma sahip olduğu düşünülebilir. Bu doğrultuda üstün zekalı ve yetenekli öğrencilerin eğitimlerinin uygun şekilde zorlaştırılmasında ve karmaşıklaştırılmasında biyoloji alanı fayda sağlayabilir.

Araştırmada diğer bir sonuç ise, üstün zekalı ve yetenekli öğrencilerin üstün zekalı ve yetenekli olmayan öğrencilere göre 'Araştırıcı ve bilgi sağlayıcı olarak biyoloji' kategorisindeki metaforları daha fazla oluşturdukları belirlenmiştir. Yani üstün zekâlı ve yetenekli öğrenciler üstün zekalı ve yetenekli olmayan öğrencilere göre; inceleme, deney, büyüteç, kalem, ayna, XRay ve tornavida gibi metaforları daha fazla kullanmışlardır. Bu durumun, üstün zekalı ve yetenekli öğrencilerin özelliklerinden kaynaklandığı düşünülebilir. Çünkü Stuart ve Beste (2011) üstün zekâlı ve yetenekli öğrencilerin fen bilimlerine, insanın tabiatına ve evrene karşı büyük ilgi gösterdiklerini ifade etmiştir. Bu öğrencilerin yüksek ilgi ve meraklarını bilimsel yöntemlerle araştırmak ve bilgi elde etmek için mikroskop, büyüteç, teleskop vb. bilimsel araç gereçlere karşı yaşıtlarına göre daha fazla ilgi duyduklarını ve bu araç gereçleri daha iyi kullanabildiklerini vurgulamıştır. Ayrıca bu öğrenciler bilimsel araç gereç ve cihazları kullanmayı ve bunları kullanarak öğrenmeyi sevmektedirler (Stuart ve Beste, 2011). Sonuç olarak hem üstün zekalı ve yetenekli öğrencilerin biyoloji eğitimlerinin öğrenci ilgi ve merakları doğrultusunda farklılaştırılmasında hem de üstün zekalı ve yetenekli olmayan öğrencilerin öğrenmelerinde öğrencilerin biyoloji ile ilgili olayları, insan tabiatını ve evreni keşfetmeleri, araştırıcı ve bilgi sağlayıcı olarak mikroskop ve büyüteç gibi araç gereçlerin kullanılması sağlanabilir, öğrencilerin yaparak ve yaşayarak öğrenmelerine imkan sunulabilir.

Araştırmada üstün zekalı ve yetenekli olmayan öğrencilerin üstün zekalı ve yetenekli öğrencilere göre 'bilim olarak biyoloji' kategorisindeki metaforlara daha fazla vurgu yaptıkları görülmektedir. Bu sonuç üstün zekalı ve yetenekli olmayan öğrencilerin biyolojinin yapısal özelliğine yönelik algılarının daha yoğun olduğu şeklinde düşünülebilir. Çünkü öğrenciler ağaç, brokoli, örümcek, geniş aile, daire gibi oluşturduğu metaforlar ile biyolojinin alt bilim dallarına ve bilim olarak yapısına vurgu yapmışlardır. Bu sonuca göre üstün zekalı ve yetenekli olmayan öğrencilerin biyoloji öğrenmelerinde biyolojinin alt bilim dallarına ve özelliklerine daha fazla vurgu yapilabilir.

Sonuçta hem üstün zekâlı ve yetenekli öğrencilerin hem de üstün zekalı ve yetenekli olmayan öğrencilerin genel olarak biyolojiye yönelik olumlu duygu ve düşünceye sahip olduğu düşünülmektedir. Öğrenciler sadece olumsuz bir duygu kaynağı olarak biyoloji ve anlaşılmaz, karmaşık ve zorlayıcı olarak biyoloji kategorilerinde kullanılan metaforlar (sıkıcı, gereksiz ve iğrenç, can yakar vb.) dışında genelde biyolojiye yönelik olumlu duygu ve düşünce içeren 
(yaşam, yaşamın parçası, canlı, araştırma, eğlenceli, oyun, parti, arkadaş/dost, su, hava, profesör, harika vb. metaforlar) metaforların kullanıldığg belirlenmiştir. Bu sonuçlar alan yazında yer alan Yapıcı (2015), Gürbüzoğlu Yalmancı ve Aydın (2013) ve Ulukök vd., (2015)'in çalışmalarında da ortaya koyduğu gibi öğrencilerin genelde biyolojiye yönelik olumlu duygu ve düşünce içeren metaforlara ait bulgularla örtüşmektedir. Bu sonuç biyoloji eğitimi açısından ümit vericidir. Ancak biyolojiye karşı olan bu olumlu algının ilerleyen sınıflarda devam etmesi biyoloji eğitiminin öğrencilerin ilgi, merak, gereksinim, beklenti vb. göre düzenlemesi ile sağlanabilir. Çalışmada bazı öğrencilerin biyolojiye yönelik olumsuz bir algı oluşturduğu da fark edilmiştir. Örneğin; zor, karmaşık, iğrenç, savaş, Çince, can yakar, gereksiz vb. olumsuz algı içeren metaforlar belirlenmiştir. Bu olumsuz duygu ve düşünceler öğrencilerin biyolojiye yönelik motivasyon ve tutumlarını düşürebilir ve böylece ileriki yıllardaki hayatlarında biyoloji öğrenmelerinde engel oluşturabilir (Yapıc1, 2015). Bu nedenle öğrencilerin biyolojiye yönelik olumsuz algılarının öğrencilerin gereksinimleri, beklentileri, bireysel farklılıkları, ilgi ve merakları gibi özellikler dikkate alınarak iyi planlanmış bir eğitimle-öğretim süreciyle olumlu hale dönüştürülmelidir.

Araştırmada elde edilen sonuçlar doğrultusunda şu önerilerde bulunulabilir:

- Öğrencilerin biyoloji kavramına yönelik oldukça zengin, anlamlı ve farklı bakış açılarıyla birçok sayıda ve çeşitte metaforlar ortaya koydukları görülmüştür. Bu nedenle hem üstün zekalı ve yetenekli öğrencilerin biyoloji eğitimlerinin farklılaştırılmasında hem de üstün zekalı ve yetenekli olmayan öğrencilerin biyoloji derslerinde biyoloji konularını öğrenirken etkinliklerde metafor kullanımına özendirilebilir ve öğrenmelerine katkı sağlayabilir (Jeppsson, Haglund, Amin ve Strömdahl, 2013).

- Biyoloji derslerinde ve konularında öğrencilerin metaforlar üretmesi teşvik edilerek öğrencilerin derslere dikkati çekilebilir. Öğrencilerin ürettikleri metaforlar yardımı ile tartışma ortamları oluşturulabilir.

- Üstün zekalı ve yetenekli öğrencilerin gereksinimleri, ilgi ve merakları doğrultusunda biyoloji eğitimleri farklılaştırılmalıdır. Böylece öğrencilerin olumlu algıları süründürülebilir ve artır1labilir.

- Biyoloji eğitimi gerçekleştirilirken konuların günlük yaşantı ve günlük kullanımına önem verilmelidir. Ayrıca konuların insan sağlığı ve sağlıklı beslenme noktalarına vurgu yapılabilir. Böylece öğrencilerin algıları ile konular ilişkilendirilebilir.

- Öğrencilerin biyoloji kavramına ilişkin algılarını ortaya çıkarmada bir araştırma aracı olarak kullanılan metaforlar, hem üstün zekalı ve yetenekli öğrencilerin hem de üstün zekalı ve yetenekli olmayan öğrencilerin biyoloji ve biyoloji konuları ile ilgili algılarını belirlemek için daha fazla metafor çalışması yapılabilir.

- Bu çalışmaya benzer çalışmalar boylamsal şekilde tekrarlanarak hem üstün zekalı ve yetenekli öğrenciler hem de üstün zekalı ve yetenekli olmayan öğrenciler de yaş ya da sınıf seviyesi olarak yaşanan algısal değişimler gözlemlenebilir. 
Üstün zekâlı ve yetenekli olan ve üstün zekâlı ve yetenekli olmayan öğrencilerin biyolojiye ilişkin algılarının karşılaştırılması: Metaforik çalışma

\section{Kaynakça}

Açışlı, S. ve Kolomuç, A. (2012). Fen bilgisi öğretmen adaylarının fen branşlarına karşı tutumlarının incelenmesi. X. Ulusal Fen Bilimleri ve Matematik Eğitimi Kongresi, Niğde, 27-30 June 2012.

Akarsu, F. (2004). Üstün yetenekliler/Enderun: Üstün yetenekliler için saray okulu. 1. Türkiye Üstün Yetenekli Çocuklar Kongresi Seçilmiş Makaleler Kitabı, İstanbul: Çocuk Vakfı Yayınları, 127154.

Aktamış, H. ve Dönmez, G. (2016). Metaphoric perceptions of students' towards science course, science, science teacher and scientist. Ondokuz Mayis University Journal of Faculty of Education, 35(1), 730 .

Akturan, U. ve Esen, A. (2008). Fenomenoloji, Nitel Araştırma Yöntemleri (Qualitative Research Methods), (eds. Baş, T. and Akturan, U.). Ankara: Seçkin Publishing.

Al-Zahrani, A. (2008). "Darwin's metaphors revisited: Conceptual metaphors, conceptual blends, and idealized cognitive models in the theory of evolution". Metaphor and Symbol, 23, 50-82.

Andrzej, K. K. (2002). "Grand metaphors of biology in the genome era". Computers \& Chemistry, 26(5), 397-401.

Ataman, A. (2009). Special needs children and introduction of special education. Gifted and talented children. Ankara: Gündüz Education and Publishing.

Baykoç, N. (2014). Üstün; akıl, zeka, deha, yetenek, dahiler-savantlar gelişimleri ve eğitimleri.. Ankara: Vize Yayıncılık.

Büyüköztürk, Ş., Çakmak E. K., Akgün, Ö. E., Karadeniz Ş. ve Demirel, F. (2011) Bilimsel araştırma yöntemleri Ankara: Pegem Academic Publishing

Cerit, Y. (2008). Öğretmen kavramı ile ilgili metaforlara ilişkin öğrenci, öğretmen ve yöneticilerin görüşleri. Journal of Turkish Educational Sciences, 6(4), 693-712.

Cerrah, L., Özsevgeç, T. ve Ayas, A. (2005). Knowledge level of prospective biology teachers on 11th grade national biology curriculum: Trabzon sample. Inonu University Journal of Education Faculty, 6(9), 15-25.

Çağlar, D. (2004). Üstün Zekâlı Çocukların Eğitim ve Öğretimi. 1. Türkiye Üstün Yetenekli Çocuklar Kongresi Üstün Yetenekli Çocuklar Seçilmiş Makaleler Kitabı, İstanbul: Çocuk Vakfı Yayınları, 265-274.

Davis, G.A. \& Rimm S. B. (2004). Educated of the gifted and talented (Fifth Edition) Boston: Pearson Education.

Ekici, G. (2016). Determination of the preservice biology teachers' perceptions of microscope: example for metaphor analysis. Ahi Evran Üniversitesi Kırşehir Eğitim Fakültesi Dergisi, 17(1), 615-636.

Fredriksson, A. \& Pelger, S. (2016). Metaphorical concepts in molecular biology students' texts-a way to improve subject-matter understanding. Nordic Studies in Science Education, 12(1), 90-106.

Girmen, P. (2007). İlköğretim öğrencilerinin konuşma ve yazma sürecinde metaforlardan yararlanma durumlart. Doktora tezi, Anadolu Üniversitesi, Eskişehir.

Guerrero, M. \& Villamil, S. (2002). Metaphorical conceptualizations of ESL teaching and learning. Language Teaching Research, 6, 95-120.

Gül, Ş. ve Yeşilyurt, S. (2010). Ortaöğretim öğrencilerinin biyoloji ve biyoloji dersine yönelik tutumları (Pilot Uygulama), Mehmet Akif Ersoy Üniversitesi Ĕ̌itim Fakültesi Dergisi, 10(20), 28 - 47.

Gürbüzoğlu Yalmancı, S. ve Aydın, A. (2013). Pre-service teachers' metaphorical perceptions towards biology. Mustafa Kemal University Journal of Social Sciences Institute, 10(21), 208-223.

Harrison, A. G. \& Treagust, D. F. (2006). Teaching and learning with analogies. In metaphor and analogy in science education, Springer Netherlands.

Heijkoop, M. E. A. (2013). The meaning secondary school students attribute to genome metaphors Master thesis. Freudenthal Institute for Science and Mathematics Education Universiteit Utrecht, Faculteit Bètawetenschappen, http://dspace.library.uu.nl/handle/1874/267506. 
Hellsten L. \& Nerlich, B. (2011). "Synthetic biology: building the language for a new science brick by metaphorical brick". New Genetics \& Society, 30(4), 375-397.

Inbar, D. (1996). The free educational prison: Metaphors and images. Educational Research, 38(1), 77-92.

Jensen, F. N. (2006). Metaphors as a bridge to understanding educational and social contexts. International Journal of Qualitative Methods, 5(1), 1-17.

Jeppsson, F., Haglund, J., Amin, T. G. \& Strömdahl, H. (2013). Exploring the use of conceptual metaphors in solving problems on entropy. Journal of the Learning Sciences, 22(1), 70-120.

Kahyaoğlu, M. ve Kırıktaş, H. (2016). Ortaöğretim ve üniversite öğrencilerinin "doğa" kavramına ilişkin algılarının metafor analizi yoluyla incelenmesi. Marmara Coğrafya Dergisi,, 33, 58-76.

Karaçam, S. ve Aydın, F. (2014). Ortaokul öğrencilerinin teknoloji kavramına ilişkin algılarının metafor analizi. Gaziantep University Journal of Social Sciences, 13(2), 545-572.

Kontaş, H. (2009). BILLSEM öğretmenlerinin program geliştirme ihtiyaçlarına ilişskin gelişstirilen programın etkililiği. Doktora Tezi, Hacettepe, Ankara, Ankara.

Kontaş, H. (2010). Learning strategies of gifted elementary students. Elementary Education Online, 9(3), $1148-1158$.

Kök, B. (2012). Üstün zekâll ve yetenekli öğrencilerde farklllaştırllmış geometri öğretiminin yaratıcllığa, uzamsal yeteneğe ve başartya etkisi. Doktora Tezi, İstanbul Üniversitesi, İstanbul.

Lakoff, G. (1993). The contemporary theory of metaphor. In A. Ortony (Ed.), Metaphor and thought (2nd ed.). Cambridge: Cambridge Univ. Press

Lakoff, G. \& Johnson, M. (1980). Metaphors we live by. Chicago: University of Chicago Press.

Levent F. (2014). Üstün yetenekli çocukları anlamak. (2. Baskı). Ankara: Nobel Akademik Yayıncılık.

MEB BİLSEM Yönergesi, (2007). Milli Eğitim Bakanllğı Bilim ve Sanat Merkezleri Yönergesi. Retrieved from http://mevzuat.meb.gov.tr/html/25930.html.

Miles, M.B. \& Huberman, A.M. (1994). Qualitative data analysis. Thousand Oaks, CA: Sage.

Ocak, G. ve Gündüz, M. (2006). Eğitim fakültesini yeni kazanan öğretmen adaylarının öğretmenlik mesleğine giriş dersini almadan önce ve aldıktan sonra öğretmenlik mesleği hakkındaki metaforlarının karşılaştırılması. Afyon Kocatepe University Social Sciences Journal, 8(2), 293-311.

Özarslan, M. (2015). Proje paydaşlarının BILLSEM biyoloji projeleri hakkindaki düşünceleri ve bu projelerin üstün zekalı ve yetenekli ögrencilerin biyoloji ögrenmeye yönelik motivasyonlart ile bilimsel tutumlarına etkisi.. Doktora Tezi, Balıkesir Üniversitesi, Balıkesir.

Palancı, M. (2004). Üstün yetenekli öğrencilerin ihtiyaçlarını karşılamaya yönelik gerçeklik terapisi temelli okul rehberlik ve psikolojik danışma hizmetleri modeli. Üstün Yetenekli Çocuklar Bildiriler Kitabı, İstanbul: Çocuk Vakfı Yayınları, I. Türkiye Üstün Yetenekli Çocuklar Kongresi Yayın Dizisi.

Pallant, J. (2001). SPSS survival manual. Maidenhead, PA: Open University Press.

Sak, U. (2012). Üstün zekâlllar: Özellikleri tanılanmaları 2. Baskı, Ankara: Vize Publishing.

Selvi, M. (2007). Biyoloji öğretmen adaylarının çevre kavramları ile ilgili algllamalarının değerlendirilmesi. Doktora Tezi, Gazi Üniversitesi, Ankara

Stuart T. \& Beste, A. (2011) Farklı olduğumu biliyordum: Üstün yeteneklileri anlayabilmek, Ankara: Kök yayınc1lk, 3. Baskı.

Strauss, S. (2009). A metaphor for DNA? New Scientist, 201(2696), 22.

TDK (2016). Büyük Türkçe sözlük, 14.07.2016 Retrieved from http://www.tdkterim.gov.tr/bts/.

Turhan Türkkan, B. ve Yeşilpınar Uyar, M. (2016). The metaphors of secondary school students towards the concept of "Mathematical problem". Çukurova Üniversitesi Eğitim Fakültesi Dergisi, 45(1),99-130. 
Üstün zekâlı ve yetenekli olan ve üstün zekâlı ve yetenekli olmayan öğrencilerin biyolojiye ilişkin algılarının karşılaştırılması: Metaforik çalışma

Tomlinson, C. A. (2015). Üstün zekâlı ve yetenekli ögrencilerin bulunduğu sınıflarda karma ögrretim, Ankara: Anı Yayıncılık.

Tortop, H.S. (2015). Üstün zekâlılar eğitiminde farklılaştırılmış ögrretim müfredat farklılaştırma modelleri. Düzce: Genç Bilge Yayıncılık.

Töremen, F. ve Döş, İ. (2009). İlköğretim öğretmenlerinin müfettişlik kavramına ilişkin metaforik alg1lar1. International Journal of Educational Reform, 13(3), 295-306.

Ulukök, Ş., Bayram, K. ve Selvi, M. (2015). Pre-service science teachers' mental images towards biology concept (Metaphor analysis sample). International Online Journal of Educational Sciences,7(3),244-259.

Van Tassel-Baska, J. \& Stambaugh, T. (2009). Üstün zekâlı ve yetenekli öğrenciler için eğitim programı. İstanbul: Bilimsel Açılım Academic Publishing., 315-333.

Yapıcı, Ü. İ. (2015). Lise öğrencilerinin biyoloji kavramına ilişkin metaforik algıları. Electronic Journal of Social Sciences, 14(55),139-147.

Yıldırım, A. ve Şimşek, H. (2008). Nitel araştırma yöntemleri (7.baskı). Ankara: Seçkin Yayıncılık. 


\section{Extended Abstract}

\section{Introduction}

While students perceive the concepts, they usually assimilate the concept that they want to comprehend to other one and metaphors come to the forefront (Ocak and Gündüz, 2006; Yapıc1, 2015). Some various metaphors are utilized in order to learn subjects in Biology. This study will make contributions to reveal gifted and non-gifted students' perceptional differences towards Biology. By this means, Biology education will be differentiated so as to meet the needs, interests and curiosity of gifted and talented and non-gifted students. The study is fulfilled with the purpose of comparing gifted and non-gifted students' perception of Biology through metaphors.

\section{Methodology}

In this study, "phenomenology design" from quantitative research designs suitable to research nature is used. In order to determine the study group, convenience sampling method is decided (Büyüköztürk et al., 2011). The participants consist of 82 gifted and talented students participating in two different cities of Science and Art Centre in Marmara region and 82 nongifted students who get education in a secondary school and a Vocational and Technical Anatolian High School in the same region in the spring term of 2014-2015 education year. The students at the age of 11 and 15 are included in the study.

In the study, it is known that gifted and talented students have knowledge about Biology since they carry out activities in the field of Biology at the secondary school level of Science and Art Centre programs. However, non-gifted students may not recognize the field of Biology wholly as they are educated at the secondary school level of Science course. Therefore, the field of Biology in Science course is introduced to non-gifted students by Science and Technology teacher. For this purpose, students are informed about biology subjects and the field of study and asked to prepare weekly performance tasks. Students share their performance tasks with the other peers in the class and exhibit their posters and panels to their friends for a week. The phase of collecting the study data is fulfilled after the indicated implications are completed. In accordance with metaphor studies in the literature, students are asked to complete the sentence "Biology is like......./similar to.....; because....." so as to determine the students' metaphors towards Biology. The data is analyzed with the help of content analysis method.

\section{Findings and Discussion}

In the research, it is determined that both gifted and talented students and non-gifted students generally emphasize on life/experience metaphors towards Biology and they relate Biology with the life. It is confirmed that gifted and talented students create more various metaphors $(79.2 \%$; $53.6 \%$ ) and emphasize on more negative emotions and thoughts, searcher and information provider dimension than non-gifted students do. In the research, it is retained that non gifted students lay emphasize more on the healthy side of Biology and its complicated and difficult than gifted and talented students do. Nevertheless, there is not any found statistically significant difference between the gifted and non-gifted students' perceptions towards Biology concepts. 